\title{
Origin of an enigmatic regional Mio-Pliocene unconformity on the Demerara plateau
}

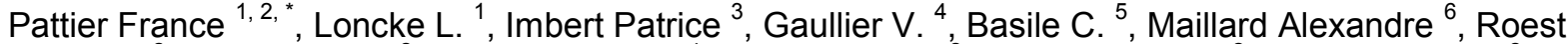 \\ Walter $^{2}$, Patriat Martin ${ }^{2}$, Vendeville B. C. ${ }^{4}$, Marsset Tania ${ }^{2}$, Bayon Germain ${ }^{2}$, Cathalot Cecile ${ }^{2}$, \\ Caprais Jean-Claude ${ }^{2}$, Bermell Sylvain ${ }^{2}$, Sotin Christine ${ }^{7}$, Hebert Bertil ${ }^{7}$, Mercier De Lepinay Marion ${ }^{7}$ \\ ${ }^{8}$, Lebrun J. F. ${ }^{9}$, Marcaillou B. ${ }^{9}$, Heuret A. ${ }^{9}$, Droz Laurence ${ }^{10}$, Graindorge David ${ }^{10}$, Poetisi E. ${ }^{11}$,
} Berrenstein H. ${ }^{11}$

${ }^{1}$ Univ Perpignan Via Domitia, Ctr Format \& Rech Environnements Mediterraneens, UMR 5110, F66860 Perpignan, France.

${ }^{2}$ UR Geosci Marines, Inst Carnoilfremer EDROME, Ctr Brest, IFREMER, F-29280 Plouzane, France.

${ }^{3}$ Total CSTJF, F-64000 Pau, France.

${ }^{4}$ Univ Lille 1, CNRS, Lab Oceanol \& Geosci, UMR 8187, F-59655 Villeneuve Dascq, France.

${ }^{5}$ Univ Grenoble 1, Observ Sci Univ Grenoble, ISTerre, UMR CNRS 5275, F-38400 St Martin Dheres, France.

${ }_{7}^{6}$ Univ Toulouse 3, GET OMP, F-31400 Toulouse, France.

${ }^{7}$ CEFREM, Perpignan, France.

${ }^{8}$ TOTAL SA, Paris, France.

${ }^{9}$ Univ Antilles Guyane, St Claude, France.

${ }^{10}$ Univ UBO Brest, Brest, France.

${ }^{11}$ Univ Paramaribo, Paramaribo, Surinam.

* Corresponding author : France Pattier, email address : france.pattier@univ-perp.fr

\begin{abstract}
:
The Demerara plateau, located offshore French Guiana and Suriname, is part of a passive transform continental margin particularly prone to develop slope instabilities, probably in relation to the presence of a free distal border along its steep continental slope. Slope failure occurred at different periods (Cretaceous to Neogene) and shows an overall retrogressive evolution through time. Upslope these failure headscarp, an enigmatic regional MioPliocene unconformity has been discovered through the interpretation of new academic and industrial datasets. The aim of this work is to describe and understand the origin of this surface. Our analysis shows that this unconformity is made of a series of valleys that cross-cut sedimentary strata. Each one of these valleys has a short lateral extent and is closed along two perpendicular directions, which suggests that it could correspond to a highly meandering system, or to some sub-circular depressions. The infill of these features is equivalent to the regional stratigraphic strata found outside the structures, but in a subdued position. This seems to imply that the structures have originated by a local loss of sediments at their base or by sliding processes. Furthermore, these depressions intersect each other through time, while migrating progressively downslope. We discuss a series of hypotheses that try to explain the onset and evolution of these
\end{abstract}


depressions forming the Mio-Pliocene unconformity (Canyons? Slope failures? Contourite moats? Hydrate pockmarks?). Having established that these structures are depressions formed by collapse, and have many similarities with structures recently described in the literature as pockmarks associated with gas hydrate dissolution, we favor this hypothesis. We propose that these hydrate pockmarks form with a mass failure that was triggered by fluid-overpressure development at the base of the hydrate stability zone.

\section{Highlights}

- We investigated enigmatic regional Mio-Pliocene unconformity on the Demerara plateau. This unconformity is marked by fossil sub-circular valleys. Reflectors have collapsed or disappeared within depressions. We discuss their origin: canyon, MTD, contourite, hydrates pockmarks? We propose a relationship between fossil valleys, MTD and sliding dynamics.

Keywords : Unconformity, Hydrate pockmark, Slide, Contourite, Valley, Canyon, Demerara plateau 


\section{Introduction}

The Demerara plateau, conjugated of the Guinean plateau (Benkhelil et al., 1995) derives from the successive openings of the Central and Equatorial Atlantic oceans. It occupies a key role in the opening of the Atlantic Ocean, forming one of the last gateways before complete connection. It forms a wide basin lying on extended continental crust (Greenroyd et al., 2008a), bounded by divergent and transform-derived continental slopes (Gouyet, 1988; Basile et al., 2013). The first investigations about the geology of the Demerara plateau began in the seventies when several oil companies tried to assess the petroleum potential of the margin. Several wells were drilled but none of them showed any commercial interest. A first, description of the Demerara plateau structure and history was made publicly available through Gouyet's (1988) Ph.D. work. This synthesis evidenced the peculiar structure of the northern border of Demerara plateau, showing transpressional folded series eroded by a prominent Albian unconformity. During the early 2000's, studies took a different directions. Several wells were drill as part of the Ocean Drilling Program (Erbacher et al., 2004; Mosher et al., 2007) along the Northeastern edge of the plateau. The aim was to study Cretaceous to Paleogene paleoceanographic conditions of the tropical Atlantic taking in advantage of the key location of the plateau. Another argument that motivated the choice of this site was the fact that the Cretaceous and Paleogene sediments were shallowly buried, sometimes nearly outcropping near the transform-derived continental-slope. In parallel, industrial acquisitions increased, which allowed the discovery of interesting prospects along the plateau. In 2003, a nearly complete mapping of the French part of the plateau was performed as part of the program for the extension of the French continental shelf EXTRAPLAC. The analysis of this dataset revealed that the Demerara plateau was a place of huge slope failures trending parallel to its transform edge (Loncke et al., 2009). These slope failures initiated during cretaceous times, and regular reactivations or new events were recorded until present day (Pattier et al., 2013). Numerous elongated depressions were described on the seabed on top of remobilized deposits. There were interpreted as pockmarks elongated by deep-sea bottom currents (Loncke et al., 2009; Pattier et al., 2013). In order to understand the factors that control slide onset (Fluids ascents? Structure? Currents?), another geophysical cruise was carried out in May 2013 (Loncke et al., accepted with revisions). This cruise revealed that the main failure headscarp already defined along the French Demerara plateau was continuing off Surinam, reaching $350 \mathrm{~km}$ long. It showed also that deep bottom currents were responsible for contourite deposition and that the elongated pockmarks were no more active (Loncke et al., accepted with revisions). Finally, an enigmatic regional unconformity already observed on industrial data was recognized on this new high-resolution data set. This regional unconformity affects Miocene to Pliocene sediments located upslope of the main failure headscarp. The meaning of this unconformity seems particularly important to decipher: is it related to massive slope instabilities pre-dating the last failure? Can it be related to the onset of strong deep bottom currents? Or to other phenomenon?

In order to answer to these questions that may have important academic and petroleum issues, we carried out a stratigraphic analysis of available academic and industrial seismic data from the area. We first updated the chronology and mapping of the different slope failures already described by Pattier et al., 2013. Then, we mapped the extent of the MioPliocene unconformity and analyzed its characteristics using high-resolution relative stratigraphy. Finally, we discuss the origin of this surface. 


\section{Geological setting}

\subsection{Physiographic, hydrographic and oceanographic settings of the Demerara plateau}

The study area is located in the western Equatorial Atlantic Ocean, offshore French Guiana (Figure 1.A). The Demerara plateau is a prolongation of the wide continental shelf (Figure 1.A). This plateau is $380 \mathrm{~km}$ long, $220 \mathrm{~km}$ wide and ranges in water depth from 200 to 4500 $\mathrm{m}$. It is delineated by a transform margin along its northern boundary and by divergent margins on its eastern and western boundaries (Gouyet, 1988; Unternehr et al., 1988; Greenroyd et al., 2008b; Basile et al., 2013). Our study focuses mainly on the northeastern border, where high resolution grid is the densest (blue box Figure 1.A).

The Demerara plateau has a gentle slope but its boundaries are abrupt, especially toward its transform segments. Basile et al. (2013) divided the Demerara plateau into three physiographic domains (Figure 2), based on seismic data. This partition also accounts for the slope values observed on the bathymetric data: (1) the upper plateau (slope values less than $\left.1^{\circ}\right),(2)$ the intermediate plateau (average slope value $3^{\circ}$ ), (3) the lower plateau (slope value $<1^{\circ}$ ), and (4) the continental slope (slope value on average $12^{\circ}$, with maximum values reaching $20^{\circ}$ ) (Pattier et al., 2013). The boundary between the upper and intermediate plateaus is defined by a bathymetric slope break that corresponds to a main sediment slope failure headscarp (Figure 2; Loncke et al., 2009; Pattier et al., 2013).

The continental slope shows contrasting slope values between the northern segment (i.e., the transform boundary, average slope value $15^{\circ}$ ) and the eastern segment (i.e., the divergent boundary, average slope value $4^{\circ}$ ) (Pattier et al., 2013).

Sedimentation on the Demerara plateau may be influenced by nearby rivers, the most important being the Amazon to the southeast, the Maroni at the French Guiana-Suriname border (For examples in coastal sedimentation: Jounneau and Pujos, 1988; Pujos and Froidefond, 1995), and the Orinoco to the northwest (for example in deep sedimentation: Gonthier et al., 2002). The French Guiana coast is characterized by a muddy northwestwards longshore drift. Mud banks are fed mainly by the Amazon river outwash plume (Pujos and Froidefond, 1995). Three major deep-water masses characterize the oceanographic setting in the study area (Figure 1.B): (1) the SE-NW oriented Antarctic Intermediate Water (AAIW) at 800-900 m water depth, (2) the NW-SE oriented North Atlantic Deep Water (NADW) centered at $~ 2500 \mathrm{~m}$ to $4300 \mathrm{~m}$ water depth (Gonthier et al., 2002), (3) the SE-NW oriented Antarctic Bottom Water (AABW) below $4600 \mathrm{~m}$ water depth (Stommel and Arons, 1959; Schmitz and McCartney, 1993; Hogg et al., 1996; Hogg and Owens, 1999; Gonthier et al., 2002, Dengler et al., 2004). Sediment waves, associated with contour currents flowing southwards, were described in the northeastern Demerara abyssal plain, at $\sim 4000 \mathrm{~m}$ water depth by Gonthier et al. (2002) and Loncke et al. (2009). More recently, southward flowing active contour currents have been evidenced at shallower water depth (between 1600 and $4000 \mathrm{~m}$ water depth) along the Demerara plateau (Tallobre et al., 2014; Loncke et al., accepted with revisions). They seem to relate to the North Atlantic DeepWater bottom current.

\subsection{Early evolution of the Demerara plateau (Jurassic-Albian)}

Prior to the opening of the equatorial Atlantic, the Demerara plateau was adjacent to the Guinean Plateau that belongs to the conjugate western African margin (Benkhelil et al., 1995; Erbacher et al., 2004) (Figure 1.C). Gouyet (1988), Greenroyd et al. (2008a), and Basile et al. (2013) have described the deformation history of the Demerara Plateau. The margin formed during two successive stages: (1) during the Early Jurassic, the western edge of the Demerara plateau formed as a divergent segment during the opening of the central 
Atlantic Ocean (Klitgord and Schouten, 1986; Gouyet, 1988; Unternehr et al., 1988); (2) at the end of the Early Cretaceous, the Guinean Plateau and the northern and eastern boundaries of the Demerara plateau separated during the opening of the equatorial Atlantic Ocean in a strike-slip regime along a main transform zone (Gouyet, 1988; Unternehr et al., 1988; Greenroyd et al., 2008b). Transform activity ceased in the late Albian (Gouyet, 1988; Mosher et al., 2005; Basile et al., 2013). Along the eastern edge of the Demerara plateau, the main tectonic structures are normal faults trending NNE-SSW related to the rifting. Along its northern edge, WNW-ESE to NW-SE trending acoustic basement ridge folds and thrust are interpreted as transform-related structures (Figures 1 and 2) (Gouyet, 1988; Basile et al., 2013). The end of transform activity is marked by a regional late Albian erosional unconformity.

\subsection{Passive margin evolution}

During the late Albian, most of the plateau emerged and was subjected to erosion (Gouyet, 1988; Greenroyd et al., 2008a; Basile et al., 2013).

Post-transform (post-Albian) sediments on the Demerara plateau consist of a succession of sedimentary wedges sources from the continental shelf, with a maximum total thickness of 4 to $5 \mathrm{~km}$ (Gouyet, 1988). The first post-transform sediments consist of Cenomanian marine black shales, indicative of oxygen depletion (Mosher et al., 2007). These sediments have recorded a regional transgression from the late Albian to the late Cenomanian. Clayey sediments were deposited during the late Cretaceous and clayey chalk during the Paleogene (Gouyet, 1988). During the Paleogene-Neogene transition, the eastern Demerara plateau was tilted seaward (Basile et al., 2013). Paleogene deposits are progradational on the shelf edge. The Amazon system developed in the last 10 Ma (Milliman et al., 1975) and, along with the Orinoco and Maroni rivers, has resulted in a sedimentation that became more terrigeneous with time. The ODP Leg 207 revealed a clay-dominated sedimentation during the Neogene (since 16 My; Mosher et al., 2007). The Neogene series constitute a thick progradational wedge that thins towards the outer Demerara plateau (Figure 2). Late Pleistocene and Holocene deposits are only a few meters thick, suggesting that at present, the offshore rise is sediment-starved (Ingram et al., 2011) and influenced by strong bottom currents.

\subsection{Slides and fluid-escape structures}

The seabed of the Demerara plateau is characterized by a segmented morphology, low slope gradients, a rough surface (with undulations trending perpendicular to the slope direction) and depression fields, interpreted as pockmarks (Loncke et al., 2009; Gaullier et al., 2010; Loncke et al., 2010; Pattier et al., 2011 and 2013).

Slumps initiated along the Demerara plateau between the upper and intermediate plateau (Figure 2). The sedimentary cover of the Demerara plateau off French Guiana was totally destabilized for more than $80 \mathrm{~km}$ in length and $500 \mathrm{~m}$ in thickness, as shown by numerous stacked transparent masses corresponding to large mass transport deposits (MTD's) (Figure 2) (Loncke et al., 2009; Gaullier et al., 2010; Loncke et al., 2010; Pattier et al., 2011 and 2013). Giant slumps affecting the Oligocene to recent sediments were also described in the northwesternmost part of the Demerara plateau, offshore Suriname (O'Regan and Moran, 2007; Ingram et al., 2011). Ingram et al (2011) proposed that the initiation of northwesternmost failures may relate to mid Miocene climate change, leading to massive hydrate dissociation and/or deep and intermediate water current intensification. Pattier et al. (2013) proposed that recurrent instability may relate to a combination of fluid overpressures and the peculiar structure of the transform margin. They propose that post-transform sediments hanging" on the continental slope are particularly prone to get destabilized near the oceanic, free boundary. 


\section{Dataset and methodology}

The FG02 seismic survey was acquired by FUGRO using the R/V "Professor Polshkov". It surveyed the French Guiana continental shelf, the eastern Demerara plateau and the East Guiana continental slope. A total of $7715 \mathrm{~km}$ of multichannel seismic data were collected (Figure 3) for industrial purposes. The FG02 data were processed by Robertson Research International in Perth, Australia. The shallower part of this dataset was made available by Total S.A. for this study.

The GUYAPLAC cruise was carried out onboard the R/V L'Atalante" in 2003, as a part of the French EXTRAPLAC Program (Ifremer-IFP-SHOM-IPEV). It surveyed the French Guiana margin and the adjacent Demerara Abyssal Plain. The dataset comprises: (1) SIMRADEM12 Dual multibeam bathymetry and backscatter imagery, (2) $3.5 \mathrm{kHz}$ echograms, and (3) 6-channel seismic reflection profiles (Figure 3).

The IGUANES cruise was carried out onboard the R/V "L'Atalante" in 2013 as part of scientific research led by the University of Perpignan. It surveyed the Demerara plateau. The dataset (Figure 3) comprises: (1) SIMRAD-EM122 Dual multibeam bathymetry and backscatter imagery, (2) SBP Chirp (1800-2500 Hz), (3) high-resolution 72-channel seismic reflection profiles (noted Iguanes HR on Figure 3), acquired at a speed of 5 knots, and (4) 24-channel seismic reflection profiles (noted Iguanes RS survey on Figure 3) acquired at 10 knots.

The stratigraphy used to calibrate the seismic data is provided by the correlation with the G2 industrial well site published by Gouyet (1988) (Figure 4, modified from Basile et al., 2013), and the ODP Leg 207 results (Mosher et al., 2007).

The sedimentary cover truncates deformed early Cretaceous and older rocks. The basal transgression above the unconformity is marked by a basal lag of shell debris. Above the late Albian unconformity, we recognize three units with a few intra-unit reflectors (Figure 4):

- R4 constitutes the base of Unit C. This unit corresponds to late Cretaceous sediments; it is poorly reflective, especially in its lower part, where the transparent seismic facies corresponds to the Cenomanian-Turonian black shales. This unit is made mainly of sandy claystones and claystones. C4 marks the base of Cenomanian, C2 the base of the Turonian and $\mathrm{C} 1$ the base of the Maastrichtian;

- R3 bounds the base of Unit B, which comprises four subunits: (1) Paleocene series have coherent and parallel reflectors, (2) the base (R2) of the Eocene having a transparent seismic facies, (3) a transparent Oligocene unit, and (4) early Miocene sediments. This unit is made mainly of clayey chalks and oozes. It was affected by polygonal faulting (Pattier et al., 2013);

- R1 marks the base of Unit A. This unit shows high-amplitude continuous reflectors and corresponds to the youngest shale sediments (late Miocene to Quaternary). This unit was deposited coevally with the onset of the Amazon and Maroni. Reflector A6 corresponds to the base of the middle Pliocene; the base of the Pliocene is situated between R1 and A7. Reflectors A6 to A1 could not be dated precisely, but are useful for conducting a geometrical analysis of Neogene to Quaternary geological features.

The studied Unconformity Uc affects Plio-Miocene series.

Most of the seismic interpretation was carried out using Total's in-house Sismage software. In order to integrate IGUANES newly acquired data, we later conducted an analysis of the seismic date using Kingdom Suite at University of Perpignan. All picking were realized by 
crossing the available seismic profiles. A profile-cutting tool was used to compare reflector packets. When propagation was questionable, it was not forced.

\section{Results}

\subsection{Sliding complexes}

On the intermediate plateau, the post-transform sedimentary units are not laterally continuous (Figure 5A). Indeed, these units were affected by several failure headscarps.

The headscarp 01 labelled on Figure $5 \mathrm{~A}$ is associated with mass transport deposits accumulating far downslope (see Pattier et al., 2013 for complete mapping). The basal shear surface of this slide is located in the Cenomanian Black shale series. This first instability event only affects the Cretaceous series. It thus seems to have occurred around the Cretaceous Tertiary boundary.

The headscarp 02 affects the Paleogene and Miocene series. A remnant of associated mass transport deposits (MTD) is visible in Figure 5 (labelled MTD02). The associated shear surface is located in Paleocene series characterized by clayed chalk sediment (R3, Figure $5)$. This second instability event seems to have occurred in the early Miocene because the youngest series affected are of early Miocene in age (headscarp 02; Figure 5).

The headscarp 03 is sinuous and has a semi-circular shape (in purple on Figure 5.B). It affects a polygonal fault interval. Associated MTD 03 reaches $140 \mathrm{~ms}$ in thickness near the headscarp (Figure 5.A). It erodes partly MTD 02. Its shear surface lies in the middle Miocene series characterized by highly faulted chalk sediments and corresponds to the regional erosion surface described by Ingram et al. (2011) (R1, Figure 5). The headscarp 03 (MTD 03; in purple in Figure 5) affects the late Miocene series. Therefore, this event seems to have occurred during the late Miocene or early Pliocene.

Finally, above headscarp 02, upper Miocene to recent strata (reflectors A6 to seafloor) seems to be slightly shifted laterally. This shift is marked in the modern bathymetry by a 350 $\mathrm{km}$ long bathymetric scarp. This discontinuity could correspond to a last failure headscarp (Headscarp 04 on Figure 5) or it may result from differential compaction above headscarp 02. In parallel, a huge unconformity developed upslope this bathymetric scarp (labelled Uc on Figure 5). This unconformity affects the Upper Miocene to Recent strata.

In summary, the Demerara plateau is affected by a wide slide complex. This complex consists of several separate events and associated failure headscarps and MTDs. Slope instability progressed inland through time (events 1, 2, 3 Figure 5). An important unconformity (Uc) affects the upper Miocene to recent strata upslope the bathymetric scarp labelled headscarp 04 in Figure 5.

\subsection{Extent, stratigraphy and infill of Uc unconformity}

Uc unconformity is present on an important part of the Demerara plateau (Figure 5.C). It forms a wide rim upslope the bathymetric scarp. Where headscarp 03 has been defined (i.e. in the area of high resolution study, Figure 5), the Uc unconformity forms a curved belt whose upper boundary exactly mimics the trace of headscarp 03 . Whatever the orientation of the cross-section, it appears in $2 \mathrm{D}$ as a smooth surface, marked by numerous valleys that truncate series. Each of the valleys is several $\mathrm{km}$ wide. The slope of the valleys flanks is $3^{\circ}$.

This smooth unconformal surface truncates R1 to A2 reflectors (Figure 6). The valleys are infilled with onlapping sediments. Surprisingly, stratigraphic correlations and seismic picking 
show that these onlapping sediments have nearly the same age than sediments intersected by the unconformity: reflectors A6 to A2 are present in and outside the valleys (Figure 6). In the valleys, they appear in a subdued position.

We distinguish three classes of valleys based on the geometry of their infill (Figure 6):

(1) Type A valleys (18.5\% of valleys) show fan-shaped unconformable infill (Figure 6). Reflectors inside these features are the same as those outside, but in a lower position. They present rollover geometries (Figure 6). These follovers" are present on either side of valleys (Figure 6).

(2) Type B valleys (55.5\% of valleys) show bedded unconformable infill with no obvious lateral thickness change (Figure 6). Reflectors A6 to A3 subsided within these features with respect to the surrounding domains. Very often, some reflectors are absent from the base of these depressions, as if they have disappeared or were never deposited (see example of A6 in Figure 6).

(3) Type C valleys (26\% of valleys) are asymmetric structures with their infill becoming conformable going downslope (Figure 6), but with an upslope unconformable contact (Figure 6). Their infill records internal subsidence (reflectors A6 to A3) (Figure 6). Small second order internal depressions may look like pockmarks within these valleys (Figure 6). These hemi-valleys look in plan view as slide headscarps that root on MTD 03 (Figure 6).

\subsection{Shape and evolution of valleys}

We tried to map and prolong laterally the valleys forming the Uc unconformal surface. We mapped in fact the border of each valley. Because of the spacing of the available seismic lines, we can only provide rough tendencies. However, there are the following, but several interesting observations:

- First, we tried to map the extent of each individual valley by attributing it a color (Figure 7). It appeared that most of them could be prolonged only locally and were terminating in two directions, forming some sort of patches in map view. Two of these features could be quite well constrained on seismic profiles (orange and green patches in Figure 7).

- Figure 8 (A, B and C) presents selected details of three seismic profiles crossing the orange patch. Two profiles (Lines 09 and 10) are parallel to each other and perpendicular to the third one (Line 33). These three profiles show the same type $B$ valley structure visible along two perpendicular directions. Therefore, what we infer that such a valley in cross-section could be a sub-circular depression. The green patch corresponds to a type A valley (Figure 6), in which reflectors A6 to A3 collapsed. There again, this valley is visible along two perpendicular directions. Roll over folds formed towards the NE and SW along NE-SW trending profiles, and towards the SW and NE along SW-NE profiles. This suggests that the collapse occurred towards the boundaries of the feature. The downslope closure of the feature is however not well-constrained by seismic-profiles and it is possible that it prolongs downslope along it northeastern corner (see interpretation and tracklines in Figure 6).

- Another observation is that these valleys are not all synchronous. The first valleys initiated on the edge of headscarp 03. They are intersected by other ones, as illustrated in Figure 9. There, five generation of valleys" crosscut each other's towards SSE. The stratigraphy within the different valleys seems to similar to that outside of the valleys. Reflectors are subsiding from one valley to another. We mapped the propagation directions" of the identified valley patches (black arrows in Figure 7). The directions converge towards the center of the curved belt (Figure 7), 
showing a centripetal evolution in space and time (Figure 7). The most deeply rooted depressions are generally the first emplaced. They root on R1 or the nearby edge of MTD03 (Figure 8 for the orange patch, Figure 9 for the green patch).

\subsection{Relationships with deeper structures}

The pre-Albian series are folded as a result of late Albian transform activity (Gouyet, 1988, Basile et al., 2013). Basile et al., 2013 showed that compression seems to have continued slightly after the late Albian. The Two Way Travel time (TWT) map of the Albian unconformity (Figure 10A) shows two main slope breaks. Upslope, an E-W-trending slope break correlates roughly with the present continental shelf boundary. Downslope, a NW-SE-trending slope break correlates with the inflexion between the upper to intermediate plateaus. Superimposed on this general trend, several structural highs are present. They correspond at depth to anticlines. One anticline is particularly well expressed on the Albian unconformity TWTT map, and is situated under MTD 03, and the depression field is slightly west, south of MTD 03 (Figure 10A). This anticline was described in 2001 by the petroleum industry as a potential petroleum prospect (Matamata prospect). Also, several well-marked NE-SWtrending narrow grabens affect the Albian unconformity. Other smaller NW-SE-trending grabens are also visible (Figure 10A).

The Demerara plateau is also affected by two sets of faults (Pattier et al., 2013). A first fault family corresponds to a polygonal fault system mainly affecting the Oligocene to Miocene strata (R2-R1; in orange Figure 10B). The Uc unconformity occurs above this polygonal fault interval. A second fault family affects the entire post-transform sedimentary cover (in red in Figure 10B). These latter faults are the prolongation of late Albian regional faults, and their offset diminishes upward, with several faults connected on a deeper normal fault (Figure 10B). These faults may be related to differential compaction above faulted late Albian rocks. Some of these faults may connect potential deep source rocks and reservoirs (Black shales, deeper systems) with the headscarp 03 and the valleys field (Figure 10A). No bright spots or Bottom Simulating Reflector (BSR) were observed in the depression area.

\section{Interpretation}

The above observations allow us to better delineate the Uc Mio-Pliocene Unconformity discovered on the Demerara plateau and its relationships with the nearby slope failures and deep structures.

Uc is a smooth erosional surface that cuts across Mio-Pliocene R1 to A1 series (Figures 5 to 9). It results from the coalescence of several erosional surfaces (Figure 9) and is made of a series of imbricated valleys or depressions (Figure 9). Each one of the mapped individual valleys has a small patchy extent. When observed along two perpendicular directions on seismic profiles, these features look cylindrical (Figure 8). These observations suggest either that these valleys are highly meandering and rapidly intersected by others, or that these valleys could be sub-circular incisions.

Another important and surprising result concerns the infill of these valleys or depressions: the stratigraphy of the infill of these structures is similar to the regional stratigraphy outside the features (Figures 5 to 9) meaning that these valleys are not simple cut and fill structures. Inside the features, reflectors are in a subdued position, below the regional datum (Figures 5 to 9). At the top of the depressions, the reflectors are simply shifted down along the Uc Unconformity. At the bottom of the depressions, some reflectors are missing (example on Figure 6, where A6 is missing). This can be interpreted in two ways: (1) either these strata were never deposited, or (2) they have disappeared, which implies that there was a loss of 
material at the bottom of the valley. Furthermore, the sedimentary infill of Type A valleys shows rollover geometries in perpendicular directions (Figure 6). This geometry can evidence strong asymmetric sedimentary infill or show that a progressive deepening took place along the depression walls during the deposition of strata. For comparison, these structures resemble turtle structures described in salt tectonic settings where salt withdrawal at depth allows progressive subsidence through time (Vendeville and Jackson, 1992; Mauduit et al., 1997).

To summarize, A6 to A1 reflectors collapsed or vanished within depressions limited by an apparent erosional unconformity. This can be interpreted in two main ways:

- The depressions formed after or during deposition of $A 6$ to $A 1$, and their emplacement was accompanied by a basal loss of sediments. In this hypothesis the unconformity acts as a gliding plane. It is a syn-sedimentary gliding plane where rollover geometries are observed.

- The depressions formed during the deposition of $A 6$ to A1. In this case, the Unconformity is forming gradually while sediments are deposited laterally. It could resemble to a moat or truncation associated laterally to a confined sediment drift as observed in contourite environments (Rebesco et al., 2014).

In the high resolution study area, we observed that the Unconformity rims headscarp 03 through a 5 to $15 \mathrm{~km}$ curved belt (Figure 7). Where the MTD 03 is missing, the Unconformity did not form. This geometrical relationship suggests that there is a dynamic link between slope failure 3 and the unconformity. A wide Albian anticline considered as a potential prospect by oil companies lies under these features (Figure 10).

The emplacement of all these features occurred as follows:

(1) The Pre-Albian series deformed as a result of transform motion (Basile et al., 2013). This resulted in the formation of deep anticlines and grabens. Most of these structures are sealed by the Albian Unconformity R4. However, one normal fault seems to have been slightly reactivated (differential compaction?) after the Albian times (Figure 10).

(2) Cretaceous to early Miocene strata were deposited (R3-R1) above R4. A first instability event occurred during the Cretaceous (Event 1). A second instability event occurred during the Miocene (Event 2). Polygonal compactional faults form during in the Paleocene to Miocene series (Figure 10). Some of them nucleated above the underlying normal fault, allowing eventual connection between deep and Miocene reservoirs. R1 corresponds to a regional unconformity attributed by Ingram et al. (2011) to an intensification of the North Atlantic Deep Water circulation (Muller et al., 1991; Flower and Kennet, 1994; Larsen et al., 1994; Moran et al., 2006).

(3) Slightly after R1 deposition, slope instabilities occurred and led to formation of headcarp 03 and associated MTD 03. This event seems to have occurred after deposition of R1 and before deposition of A6 (Figure 5). R1 forms the basal shear of MTD 03.

(4) After the MTD 03 was emplaced, the first meandriform valleys or depressions appeared along headscarp 03 (Figures 6 and 8). The tip of the first unconformable features roots on R1 or on the top of MTD03 (Figure 6). They affect A6 to A2 sediments. Depressions were most likely initiated after deposition of A6 (A6 to A5 sediments are clearly deformed). 
(5) Finally, these valleys or depressions that form the Unconformity propagated downslope and upwards.

\section{Discussion on the origin of Uc unconformity and associated sub- circular valleys or depressions}

\subsection{The canyon hypothesis}

The depressions observed on the Demerara plateau cut across the sedimentary series and in profile view look like canyons. Therefore, they could correspond to parts of a highly meandering canyon system.

However, several observations are not compatible with this hypothesis: (1) stratigraphic correlations show that reflectors are the same within and outside these valleys; therefore they cannot be simply interpreted as cut and fill structures, (2) their infill is devoid of any high amplitude reflectors and rollover structures are not compatible with canyon dynamics; (3) the observed depressions are not located in a physiographic province showing high slope values prone to the development of canyons; (4) if we try to tentatively relate the depression field to a meandering canyon, it would imply that this pathway is globally parallel to the slope, which is difficult to explain, unless we consider that the canyon is related to longitudinal bottom currents (see section 6.3)

\subsection{The slope failure hypothesis}

Alternatively, these giant depressions may be interpreted as small semi-circular slope failures propagating upslope from the headscarp 03. Indeed, they present rollovers geometries and occur above the MTD 03 (Figure 9). Furthermore, Type C depressions show asymmetric geometries that could be interpreted as resulting from slope failures. However, several observations are uncompatible with this very tempting hypothesis: (1) the upslope depressions, despite some uncertainties, appear to be semi-circular and -closed" along the downslope direction (green and orange patches, Figures 7 and 8), (2) the depressions we mapped propagated through time in a centripetal way (Figure 11D). Especially, the seismic lines that intersect MTD 03 perpendicular to its headscarp show that, the depressions migrated downslope through time. According to a hypothesis of slope failure, a retrogressive evolution of successive sub-circular headscarps would be expected (Figure 11C); (3) collapse occured along walls that show very low slope angles $\left(\sim 3^{\circ}\right)$, well below the characteristic values for normal faults. The only way to get such low angles for normal faults may be the presence of over pressured fluids along the shear plane. Pattier et al. (2013) proposed that the numerous slides observed along the Demerara plateau could be related to fluid overpressure below low-permeability layers. However, this hypothesis based on the observation of pockmarks on the seafloor and the presence of overpressured layers at depth (O'Regan and Moran, 2007) is difficult to prove. Finally, one must notice that some depressions show not only an internal subsidence of reflectors, but also the loss of basal strata. In the slope failure hypothesis, this would mean that these strata became mobile and moved laterally. This could eventually happen in the case of very high fluid overpressures (Mourgues and Cobbold, 2003; Lacoste et al., 2011 and 2012).

\subsection{The contourite hypothesis}

Deep water currents cross the Demerara plateau longitudinally (North Atlantic Deep Water) and recent seismic data and core data (Loncke et al., accepted with reviews, Tallobre et al., 2014) show that contourite processes are active downslope from the study area. The depressions observed on the Demerara plateau cut through the sedimentary series. In crosssection view, some depressions of type $A$ and $C$ look like small mounded patch contourite 
drifts (Van Rooij et al., 2007). In Porcupine Seabight, mounded features with moderate propagation are found between coral banks (Van Rooij et al., 2007). They show an erosional base and sedimentary infill thickening towards the edge of the depressions. The development of such sedimentary structures requires the presence of a longitudinally flowing bottom current guided and accelerated by an initial irregular topography (Van Rooij et al., 2007).

In our case, the arcuate headscarp 03, forming an irregular topography, may have guided bottom currents and allowed the deposition of patch drifts or confined drifts (see Rebesco et al., 2014 for terminology). Then, active water currents and associated drifts could have migrated downslope allowing the development of apparent centripetal migration patterns (Figure 12D).

However, several observations may not be compatible with this hypothesis: (1) the major observation that is not in agreement with that is the fact that the stratigraphic succession is the same within and outside the depressions. In a typical contourite drift, valley shaped basal unconformities (moats) occur, but they are filled in by younger onlapping or downlapping sediments (see review by Rebesco et al., 2014). We tried, however, to develop this hypothesis by considering that the first series of depressions could have initiated on a masswasting derived unconformity (i.e., a surface composed by headscarp 3 and the top of MTD03) (Figure 12B). This surface could then have been filled in asymmetrically as in a confined or patch drift (Figure 12C). Then this scenario becomes extremely difficult to pursue (Figure 12D) and to make compatible with observations (Figure 12D, see the observed and predicted geometries of reflector A5). Indeed, the former high resolution seismic correlation shows that some horizons infilling the first depressions are cut by later depressions (Figure 9) and, surprisingly, that the intersected horizons are present in later depressions, just in a subsided position. We therefore favor another process that allows a shift of horizons after deposition together with creating basal unconformable surfaces (see section 6.4), (3) finally, $55.5 \%$ of depressions (type B) are bedded and do not show any internal lateral thickness changes that seem to be more typical of confined drifts.

\subsection{The hydrate pockmark hypothesis}

Finally, several observations can lead to a pockmark interpretation for this depressions field. The depressions are similar to $\mathrm{km}$-scale conical collapse structures recently described in literature as gas hydrate pockmarks that developed off Australia (Imbert and Ho, 2012). These authors described a field of circular fossil depressions from a 3D seismic dataset. Correlation of seismic reflectors outside and within the depressions showed that the depressions were the locus of large-volume material loss (collapsed or vanishing reflectors within the depressions). They compared these structures to active hydrate pockmarks (Sultan et al., 2010; Riboulot, 2011) and proposed that the loss of material within depressions was related to massive hydrate dissolution. When the dissociation of hydrate occurs within a hydrate pockmark, a part of the sediments is fluidized and expulsed to the surface. The remaining sediments then collapse and weld with underlying strata along the pockmark bottom (Imbert and Ho, 2012). The Imbert and Ho (2012) model suggests a conical failure that initiates from the Base Hydrate Stability Zone (BHSZ).

Off French Guiana, we tried to map the individual extent of the observed valleys that we later interpreted as depressions (Figure 7). This map is not based on 3D seismic data but it shows that depressions are organized as a rimmed field of depressions of varying size. Then, we tried to correlate reflectors outside and within the depressions. The result is that in most depressions (Type B, 55.5\% of depressions) patterns similar to these in the Imbert and Ho (2012) model are observed. The detailed high-resolution seismic correlations showed that some volume of material is missing at the base of these depressions (A6 in type B depressions) (Figure 6). In type C depressions (26\% of depressions), an asymmetrical 
collapse is also observed. In some other depressions, rollovers structures (type A depressions, $18.5 \%$ of depressions) show a collapse of sediments (Figure 6 ). This collapse is more continuous than is type $B$ depressions. Type $A$ depressions may also correspond to pockmarks whose activity has been continuous from A6 to A2 deposition. At present-day, the study area does not show any evidence for the presence of gas, such as Bottom Simulating Reflectors (BSR) or high-amplitude reflectors with reversed polarity. However, the unconformity lies above a regional antiform presented by the oil industry as the Matamata prospect (www.developpement-durable.gouv.fr). The ODP leg 207 results shows also that bacterial methanogenesis was active in Cenomanian series, and that some methane was trapped under Paleocene strata (O'Regan and Moran, 2007). Considering the wide set of potential guiding faults (Miocene polygonal faults or by longer fault; Figure 10B), it is thus fairly possible that gas ascents have occurred in the past and have reached MTD03 and the depression field.

If this hypothesis is correct, we have to consider that massive fields of gas hydrates have been emplaced during the late Miocene or the early Pliocene.

We tried to calculate the depth of the BHSZ during the emplacement of depressions (which starts after $A 6$ deposition). Considering a seafloor temperature of $2,6^{\circ} \mathrm{C}$ (thermal data from IGUANES cruise) and assuming a thermal gradient of $30^{\circ} \mathrm{C} / \mathrm{km}$ the lower boundary of the hydrate stability domain was located at about340 $\mathrm{m}$ depth below the seafloor at the time deposition of $A 6$ or $A 5$ ( $\pm 10 \mathrm{~m}$ with late Miocene and Pliocene known sea level variations). Considering a compaction rate of 10 to $25 \%$ for fine sediment and neglecting vertical movements, we can consider that the base of the hydrates was to be found an average 290 $\mathrm{m}$ under $\mathrm{A} 5$ or $\mathrm{A} 6$ (beginning of hydrate pockmark emplacement) and corresponded to the reflector $\mathrm{R} 1$, where the first depressions root. It is therefore possible that $\mathrm{R} 1$ reflection was in the stability zone corresponding to a "paleo-BSR" during MTD 03 initiation and the first onset of depressions. At present, no BSR could be observed on the geophysical dataset. This could be a result of a massive Mio-Pliocene degasing phase that allowed the development of wide hydrate pockmarks and the evacuation of most of the gas initially caught within hydrates.

Finally if the hydrate pockmark hypothesis is correct, several observations are not totally resolved: (1) why have depressions migrated in a centripetal way through time? (2) How to explain the geometry of type $\mathrm{C}$ depressions and the relationships that seem to exist in between slides (MTD 03) and depression emplacement? (3) Some depressions of the Demerara plateau show a syn-sedimentary collapse suggesting progressive hydrate dissociation whereas the hydrate pockmarks of the Australian example suggest an abrupt post depositional dissociation.

Figure 13 shows an evolutionary scenario that illustrates to explain how it would be possible to develop type A depressions according to the hydrate pockmark hypothesis. In this scenario, a conical failure first occurred above the BHSZ at the gas injection point (Figure $13 \mathrm{~A})$. Then, the gas hydrate infiltrated in fractures and impregnated the sediment (Figure 13B). The Pliocene and Pleistocene climatic oscillations could modify the pressure and temperature conditions on the seafloor which determine the position of the BHSZ. The BHSZ variations could produce dissolution of gas hydrate beneath (Figure 13C). The episodic (perhaps progressive) dissolution allowed the fluidization of hydrate-impregnated sediment, causing a progressive collapse of the non-impregnated sediment (Figure 13C and D). In the absence of a sufficient gas supply, hydrate pockmark ceased to function (Figure 13F). 


\section{Conclusion}

The aim of this study was to understand the origin of a regional Mio-Pliocene Unconformity observed upslope of an important slope failure complex along the Demerara plateau. Our analysis revealed that this unconformity was made of a series of valleys of short lateral extent that erode the underlying strata. This unconformity formed in different successive phases, as attested by valleys that cross-cuts each other. These valleys progressively migrated downslope and appear, on perpendicular profiles, as sub-circular features. We therefore prefer to call them depressions (meandering canyons? Pockmarks?). One very specific observation is that the infill of these depressions is the same as the regional stratigraphy outside the features, in a subdued position. Therefore, they cannot be considered as simple cut and fill structures.

Our analysis shows that the origin of these depressions is debatable. Three main possibilities include sliding processes, contourite processes, or hydrate dissociation. The sliding hypothesis, considering these depressions as arcuate-shaped successive slope failures is very tempting considering the chronic instability of the margin (Pattier et al., 2013). The observed evolution patterns are, however, not very classic for slide complexes (downslope migration of successive headscarps rather than a retrogressive evolution). The contourite hypothesis is the one that could best explain the regional extent of this unconformity and eventually the existence of longitudinal meandering and migrating canyons. However, the stratigraphic correlations within and outside the depressions are incompatible with this hypothesis. We consider the fossil hydrate pockmarks hypothesis to be most likely because it better takes into account the shape and stratigraphic characteristics of the observed features i.e., their sub-circular shape and the fact that internal layers have collapsed after deposition. This hypothesis implies that important concentrations of methane have been present from Upper Miocene to Pliocene times in this area. As that there is no actual evidence of gas hydrates at present time, most of the gas must have been released via slope instabilities and pockmarks formation. This hypothesis explains well the local observations made on the high resolution grid, but not very well the regional extent of the unconformity.

To conclude, the slope failure and hydrate pockmarks hypothesis seems the most likely to explain the development of this Mio-Pliocene unconformity. It is not excluded, however, that contourites processes could have interfered with its formation. 3D seismic data acquisition should greatly help to further validate these hypotheses and better characterize these depressions and origin.

\section{Acknowledgments}

The authors would like to thank the French EXTRAPLAC program for providing access to the GUYAPLAC dataset and Ifremer for financing the Ph.D. work of France Pattier. The French Research Program "Actions Marges" is acknowledged for supporting this project. We thank Total S.A. for granting us access to the Well G2 data and industrial data. We thank Fugro for granting us access to the FG02 survey. We thank the IGUANES team for an unforgettable cruise and access to high-resolution data.

Finally, we deeply thank Marc De Batist, Michele Rebesco and an anonymous reviewer that greatly helped us to strengthen this paper. 


\section{References}

Basile, C., Maillard, A., Patriat, M., Gaullier, V., Loncke, L., Roest, W., Mercier de Lépinay, M., Pattier, F., 2013. Structure and evolution of the Demerara Plateau, offshore French Guiana: Rifting, tectonic inversion and post-rift tilting at transform-divergent margins intersection. Tectonophysics 591, $16-29$.

Benkhelil, J., Mascle, J., Tricart, P., 1995. The Guinea continental margin : an example of a structurally complex transform margin. Tectonophysics 248, 117-137.

Dengler, M., Schott, F.A., Eden, C., Brandt, P., Fisher, J., Zantopp, R.J., 2004. Break-up of the Atlantic deep western boundary current into eddles at $8^{\circ} S$. Nature $432,1018-1020$.

Erbacher, J., Mosher, D.C., Malone, M.J., al, E., 2004. Proceedings of the Ocean Drilling Program, Initial Reports, 207.

Flower, B.P., Kennet, J.., 1994. The Middle Miocene climatic transition: east Antarctic ice sheet development, deep ocean circulation and global carbon cycling. Palaeogeogr. Palaeoclim. Palaeoecol. 108, 537-555.

Gaullier, V., Loncke, L., Droz, L., Basile, C., Maillard, A., Patriat, M., Roest, W.R., Loubrieu, B., Folens, L., Carol, F., 2010. Slope Instability on the French Guiana Transform Margin from swath-Bathymetry and $3.5 \mathrm{kHz}$ Echograms, in: Mosher, D., Shipp, R., Moscardelli, L., Chaytor, J., Baxter, C.D.P., Lee, H.J., Urgeles, R. (Eds.), Submarine Mass Movements and Their Consequences, Advances in Natural and Technological Hazards Research. Springer, $569-579$.

Gonthier, E., Faugères, J.C., Gervais, A., Ercilla, G., Alonso, B., Baraza, J., 2002. Quaternary sedimentation and origin of the Orinoco sediment-wave field on the Demerara continental rise (NE margin of South America). Mar. Geol. 192, 189-214.

Gouyet, S., 1988. Evolution tectono-sédimentaire des marges guyanaise et nord-brésilienne au cours de l'ouverture de l'Atlantique sud. University of Pau et des Pays de l'Adour.

Greenroyd, C. J., Peirce, C., Rodger, M., Watts, A.B., Hobbs, R.W., 2008a. Demerara Plateau - the structure and evolution of a transform passive margin. Geophys J Int 172, 549564.

Greenroyd, C.J., Peirce, C., Rodger, M., Watts, A.B., Hobbs, R.W., 2008b. Do fracture zones define continental margin segmentation? - Evidence from the French Guiana margin. Earth Planet. Sci. Lett. 272, 553-566.

Hogg, N.G., Owens, W.B., 1999. Direct measurement of the deep circulation within the Brazil Basin. Deep Sea Res. Part II 46, 335-353.

Hogg, N.G., Owens, W.B., Siedler, G., Zenk, W., 1996. Circulation in deep Brazil current, in: The South Atlantic: Present and Past Circulation. Wefer, G., Berger, W.H., Siedler, G., Webb, D.J, Berlin, pp. 249-260.

Imbert, P., Ho, S., 2012. Seismic-scale funnel-shaped collapse features from the PaleoceneEocene of the North- West Shelf of Australia. Mar. Geol. 332-334, 198-221.

Ingram, W.C., Mosher, D.C., Wise, S.W.J., 2011. Biostratigraphy of an upper Miocene masstransport deposit on Demerara Rise, northern South American margin. In: Shipp, C., Weimer, 
$\mathrm{P}$, and Posamentier, H (eds) Mass-transport Deposits in Deepwater Settings. SEPM Special Publication 96, SEPM, Tulsa, pp. 475-498.

Jouanneau, J.M., Pujos, M., 1988. Suspended matter and bottom deposits in the Maroni estuarine system (French Guiana). Netherlands Journal of Sea Research 22, 99-108.

King, L.H., MacLean, B., 1970. Pockmarks on the Scotian shelf. Geol. Soc. Am. Bull. 81, 3141-3148.

Klitgord, K.D., Schouten, H., 1986. Plate kinematics of the central Atlantic, in: Vogt, P.R., Tucholke, B.E. (Eds.), The Western North Atlantic Region. Geological Society of America, Boulder, pp. 351-378.

Lacoste, A., Vendeville, B.C., Mourgues, R., Loncke, L., Lebacq, M., 2012. Gravitational instabilities triggered by fluid overpressure and downslope incision - Insights from analytical and analogue modelling. J.Struct. Geol. 42, 151-162.

Lacoste, A., Vendeville, B.C., Loncke, L., 2011. Influence of combined incision and fluid overpressure on slope stability: Experimental modelling and natural applications. J. Struct. Geol. 33, 731-742.

Lacoste, A., Loncke, L., Chanier, F., Bailleul, J., Vendeville, B.C., Mahieux, G., 2009. Morphology and structure of a landslide complex in an active margin setting: The Waitawhiti complex, North Island, New Zealand. Geomorphology 109, 184 - 196.

Larsen, H.C., Saunders, A.D., Clift, P.D., et al., 1994. Seven Million Years of Glaciation in Greenland. Science 264, 952-955.

Loncke, L., Maillard, A., Basile, C., Roest, W.R., Bayon, G., Pattier, F., Mercier de Lépinay, M., Grall, C., Droz, L., Marsset, T., Giresse, P., Caprais, JC, Cathalot, C., Graindorge, D., Heuret, A., Lebrun, JF, Bermell, S., Marcaillou, B., Bassetti, M.-A., Tallobre, C., Buscail, R., Durrieu de Madron, X., Bourrin, F., Accepted with revisions. Structure of the Demerara passive transform margin and associated sedimentary processes. Preliminary results from the IGUANES cruise. Geol. Soc. London.

Loncke, L., Gaullier, V., Basile, C., Maillard, A., Patriat, M., Roest, W., Vendeville, B.C., 2010. Deep to surface processes of the French Guiana transform margin, eastern Demerara Plateau, in: Rediscovering the Atlantic: New Ideas for an Old Sea", Extended Abstracts. Presented at the II North Atlantic conjugate margins conference, Eds. R. P. Dos Reis and N. Pimentel, Lisbon, pp. 147-151.

Loncke, L., Droz, L., Gaullier, V., Basile, C., Patriat, M., Roest, W., 2009. Slope instabilities from echo-character mapping along the French Guiana transform margin and Demerara abyssal plain. Mar. Pet. Geol. 26, 711-723.

Mauduit T., Gaullier V., Guérin G. and Brun J.P., 1997. On the asymmetry of turtle-back type growth anticlines. Marine and Petroleum Geology, 14 (7-8), 763-771.

Milliman, J.D., Summerhayes, C.P., Barretto, H.T., 1975. Quaternary sedimentation on the Amazon continental margin : a model. Geol Soc Am Bull 86, 610-614.

Moran, K., Backman, J., Brinkhuis, H., Clemens, S.C., Cronin, T., Dickens, G.R., Eynaud, F., Gattacceca, J., Jakobsson, M., Jordan, R.W., Kaminski, M., King, J., Koc, N., Krylov, A., Martinez, N., Matthiessen, J., Mclnroy, D., Moore, T.C., Onodera, J., O’Regan, M., Pälike, H., Rea, B., Rio, D., Sakamoto, T., Smith, D.C., Stein, R., St John, K., Suto, I., Suzuki, N., 
Takahashi, K., Watanabe, M., Yamamoto, M., Farrell, J., Frank, M., Kubik, P., Jokat, W., Kristoffersen, Y., 2006. The Cenozoic palaeoenvironment of the Arctic Ocean. Nature 441, $601-5$.

Mosher, D., Erbacher, J., Zuelsdorff, L., Meyer, H., 2005. Stratigraphy of the Demerara Rise, Suriname, South America: a rifted margin, shallow stratigraphic source rock analogue. Presented at the American association of petroleum geologists annual meeting, Calgary.

Mosher, D.C., Erbacher, J., Malone, M.J., 2007. Proceedings of the Ocean Drilling Program, Scientific Results 207 : College Station, TX (Ocean Drilling Program).

Mourgues, R., Cobbold, P.R., 2003. Some tectonic consequences of fluid overpressures and seepage forces as demonstrated by sandbox modelling. Tectonophysics $376,75-97$.

Muller, D., Hodell, D.A., Ciesielski, P.F., 1991. Late Miocene to earliest Pliocene paleoceanography of the subAntarctic southeast Atlantic: Stable isotopic sedimentologic and microfossil evidence. Proc. Ocean Drill. Program Sci. Results 114, 459-474.

O'Regan, M., Moran, K., 2007. 15 . Compressibility, permeability, and stress history of sediments from Demerara rise. Proc. Ocean Drill. Program 207, 1-35.

Pattier, F., Loncke, L., Gaullier, V., Basile, C., Maillard, A., Imbert, P., Roest, W.R., Vendeville, B.C., Patriat, M., Loubrieu, B., 2013. Mass-transport deposits and fluid venting in a transform margin setting, the eastern Demerara Plateau (French Guiana). Mar. Pet. Geol. 46, $287-303$.

Pattier, F., Loncke, L., Gaullier, V., Vendeville, B., Maillard, A., Basile, C., Patriat, M., Roest, W.R., Loubrieu, B., 2011. Mass Movements in a Transform Margin Setting: The Example of the Eastern Demerara Rise, in: Yamada, Y., Kawamura, K., Ikehara, K., Ogawa, Y., Urgeles, R., Mosher, D., Chaytor, J., Strasser, M. (Eds.), Submarine Mass Movements and Their Consequences. Springer Netherlands, Dordrecht, pp. 331-339.

Pujos, M., Froidefond, J., 1995. Water masses and suspended matter circulation on the French Guiana continental shelf. Cont. Shelf Res. 15, 1157-1171.

Rebesco, M., Hernandez-Molina, F.J., Van Rooij, D., Wahlin, A., 2014. Contourites and associated sedimentscontrolled by deep-water circulation processes: State-of-the-art and future considerations. Mar. Geol. 352, 11-154.

Riboulot, V., 2011. Facteurs de contrôle du fonctionnement des pockmarks durant les derniers cycles climatiques. Université de Perpignan Via Domitita.

Schmitz, W.J., McCartney, M.S., 1993. On the North Atlantic Circulation. Rev. Geophys. 31, 29-49.

Stommel, H., Arons, A., 1959. On the abyssal circulation of the world ocean-l. Stationary planetary flow patterns on a sphere. Deep Sea Res. 1953 6, 140-154.

Sultan, N., Marsset, B., Ker, S., T., M., Voisset, M., Vernant, A.M., Bayon, G., Cauquil, E., Adamy, J., Colliat, J.L., Drapeau, D., 2010. Hydrate dissolution as a potential mechanism for pockmark formation in the Niger delta. J. Geophys. Reserches 115.

Tallobre, C., Giresse, P., Loncke, L., Bayon, G., Bassetti, M.-A., Randla, M., Buscail, R., Durrieu de Madron, X., Bourrin, F., Kunesch, S., Sotin, C., Serge, B., Vanhaesebroucke, M., 2014. New findings of contourite-related structures and their implications on oceanographic 
and sedimentary conditions on the Demerara Plateau (French Guiana and Surinam). Abstracts. Presented at $2^{\text {nd }}$ Deep water circulation congress: the contourite log-book, 10-12 September 2014, Ghent, Belgium.

Unternehr, P., Curie, D., Olivet, J.L., Goslin, J., Beuzart, P., 1988. South Atlantic fits and intraplate boundaries in Africa and South America. Tectonophysics 155, 169 - 179.

Van Rooij, D., Blamart, D., Kozachenko, M., Henriet, J.-P., 2007. Small mounded contourite drifts associated with deep-water coral banks, Porcupine Seabight, NE Atlantic Ocean. In Viana, A.R. and Rebesco, M. (eds) Economic and Palaeoceanographic Significance of Contourite Deposits. Geological Society, London, Special Publications, 276, 225-244.

Vendeville, B.C., Jackson, M.P.A., 1992. The rise of diapirs during thin-skinned extension. Mar. Pet. Geol. 9, 331-371.

\section{Figures}

Figure 1: A. Location of the French Guiana margin. B. The main deep currents that may interact with seafloor sedimentation are indicated by dashed arrows [Antarctic Intermediate Water (AAIW), North Atlantic Deep Water (NADW) and Antarctic Bottom Water (AABW)]. C. Reconstruction of the central Atlantic during the Albian time (Gouyet, 1988).
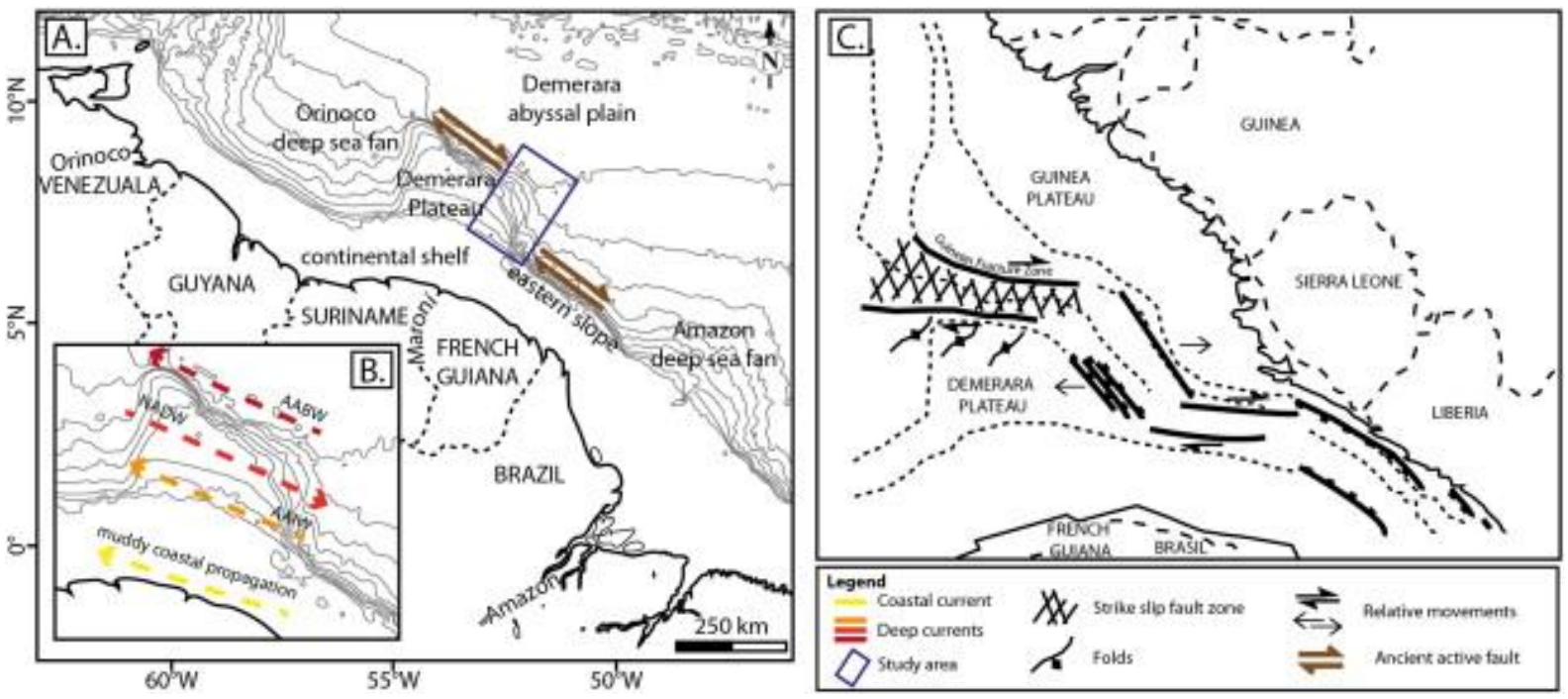
Figure 2: Interpretative geological cross sections of the outer Demerara Plateau based on combined GUYAPLAC and industrial data (Vertical Exaggeration: 20) (see locations in Figure 3).
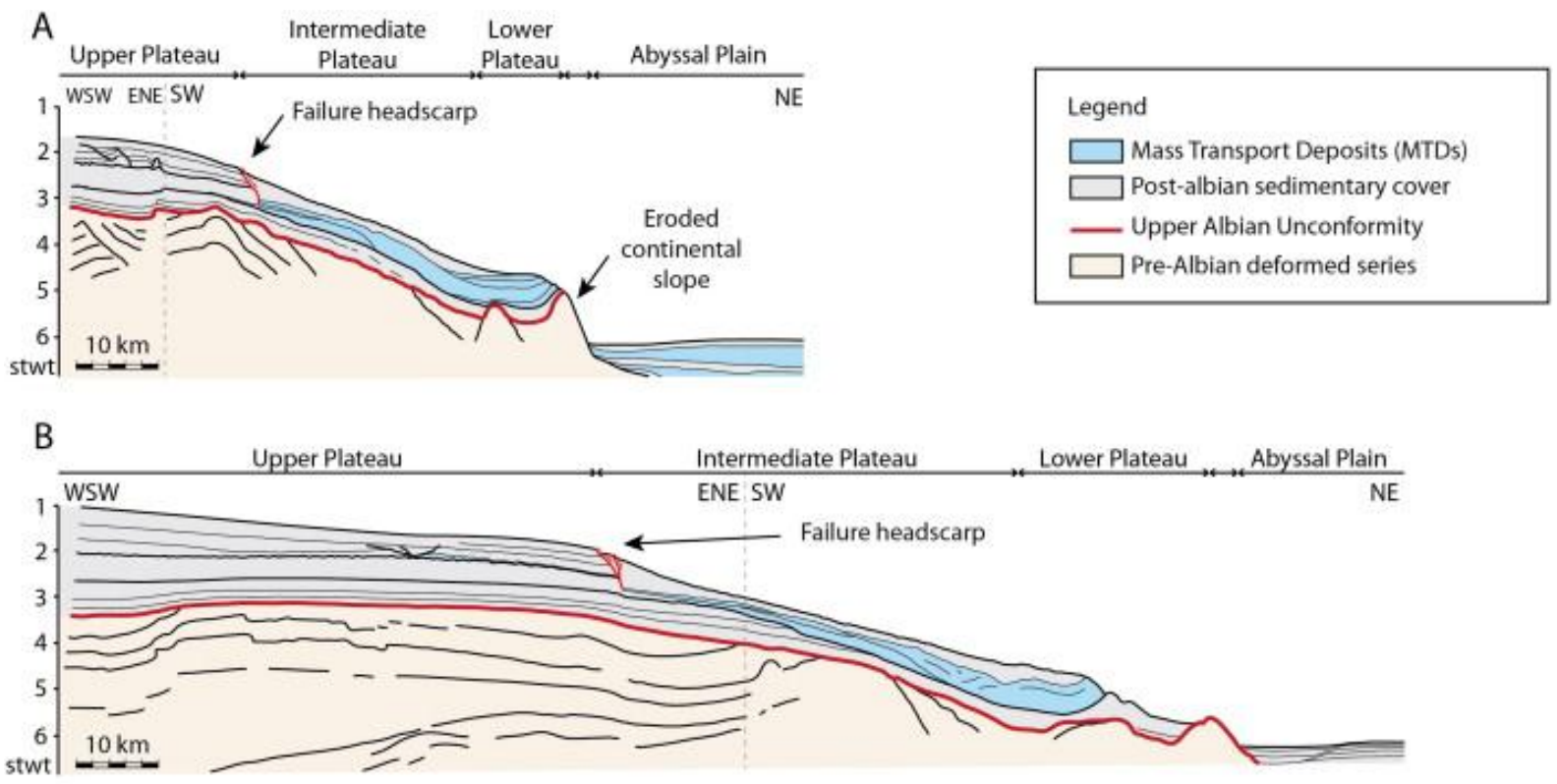

C

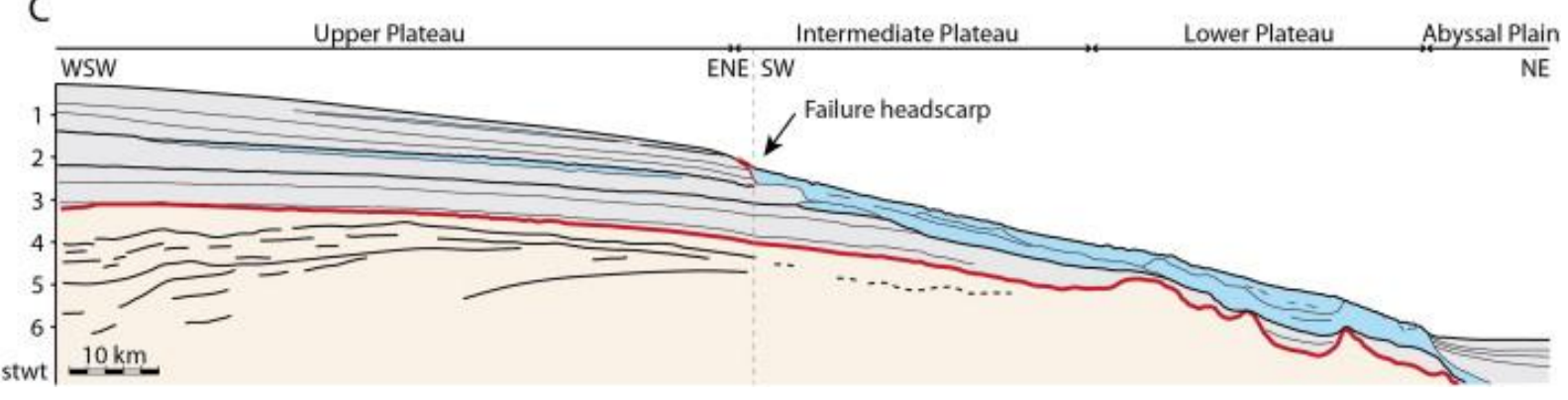


Figure 3: Tracklines of GUYAPLAC, FG02 and IGUANES surveys superposed to a bathymetric map (in meters) of the Demerara plateau. Location of seismic lines in Figures 2 and 4, location of Well G2 (Gouyet, 1988) and ODP leg 207 (Mosher et al., 2007). The yellow rectangle represents the study area.

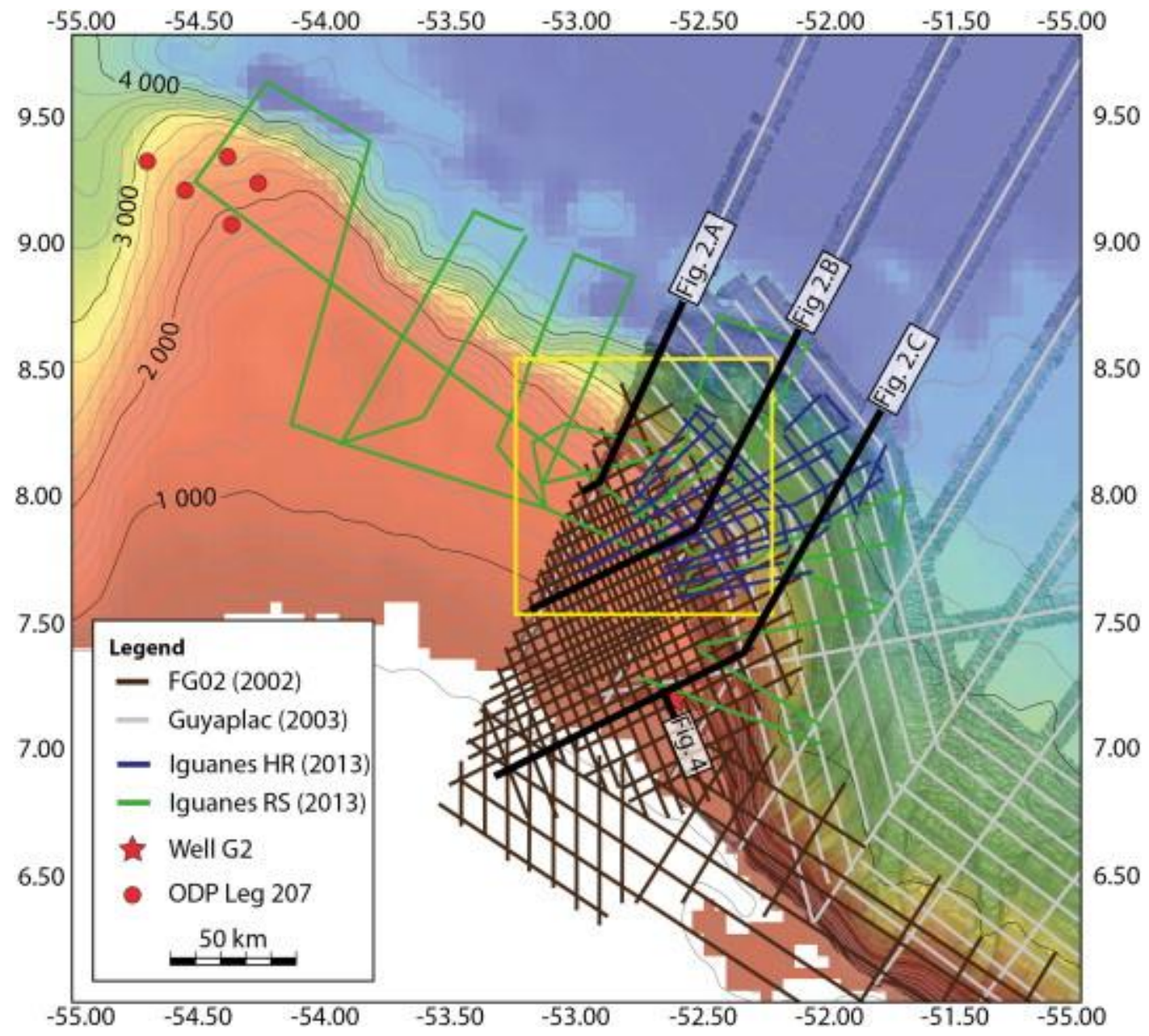


Figure 4: Seismic units on FG02 seismic line 35 (Vertical Exaggeration: 19) (see location on Figure 3). The stratigraphy (modified from Basile et al., 2013) is correlated with the G2 industrial well site published by Gouyet (1988) and the ODP Leg 207 (Mosher et al., 2007). C4 marks the base of Cenomanian, C3 the intern reflector of the Cenomanian, C2 the base of the Turonian and $\mathrm{C} 1$ the base of the Maastrichtian. Reflector A6 corresponds to the base of the middle Pliocene; the base of the Pliocene is situated between R1 and A7. Reflectors A5 to A1 could not be dated precisely.

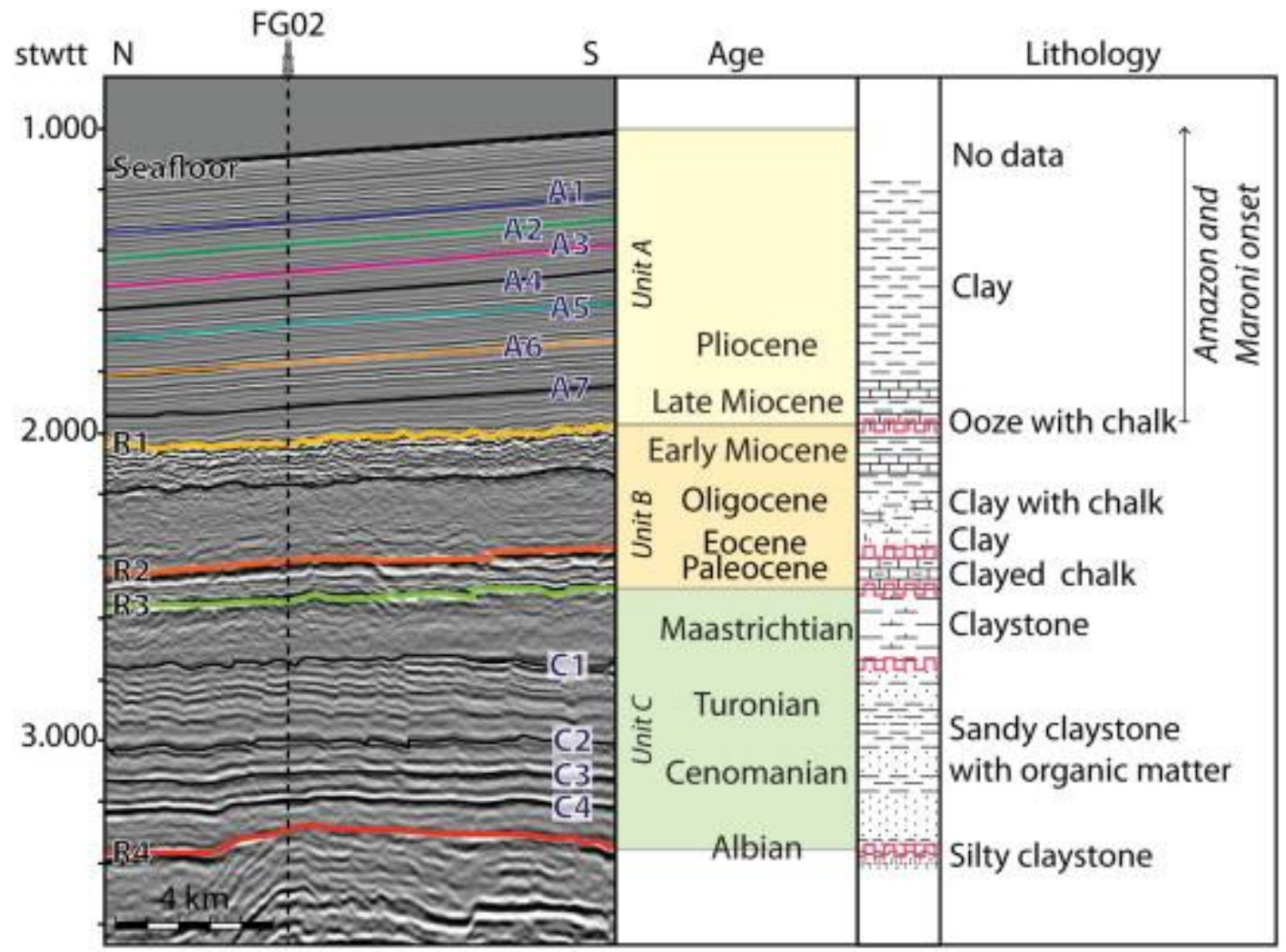

$$
\begin{aligned}
& \text { Seismic stratigraphy: } \\
& \text { R1: Miocene } \\
& \text { unconformity } \\
& \text { R3 : Top late } \\
& \text { Cretaceous } \\
& \text { Hiatus and } \\
& \text { R4 : Late Albian } \\
& \text { - R2: Top Paleocene - unconformity }
\end{aligned}
$$


Figure 5: A. Headscarps and unconformity Uc on IGUANES seismic line 43 (Vertical Exaggeration ca. 10) (Location in Figure 5.B). Numbers indicate successive main slope failure headscarps. B. Slope failure headscarps in map view and spatial extent of Uc unconformity. C. Spatial extent of Uc unconformity on the Demerara plateau.

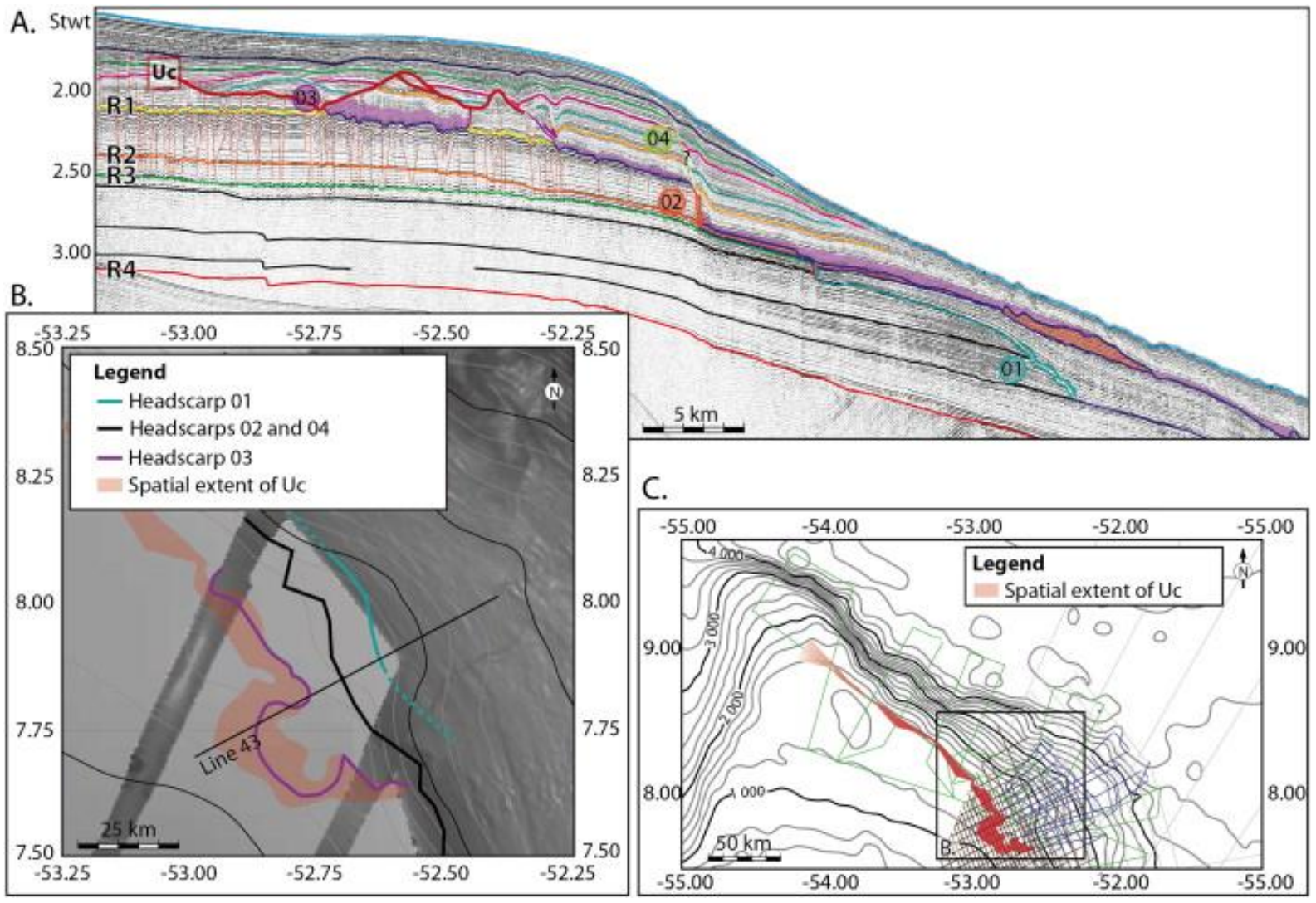


Figure 6: Types of valleys recognized in the upper Demerara Plateau on IGUANES seismic line 43 (Vertical Exaggeration 15) (See location in Figures 5B and 7).

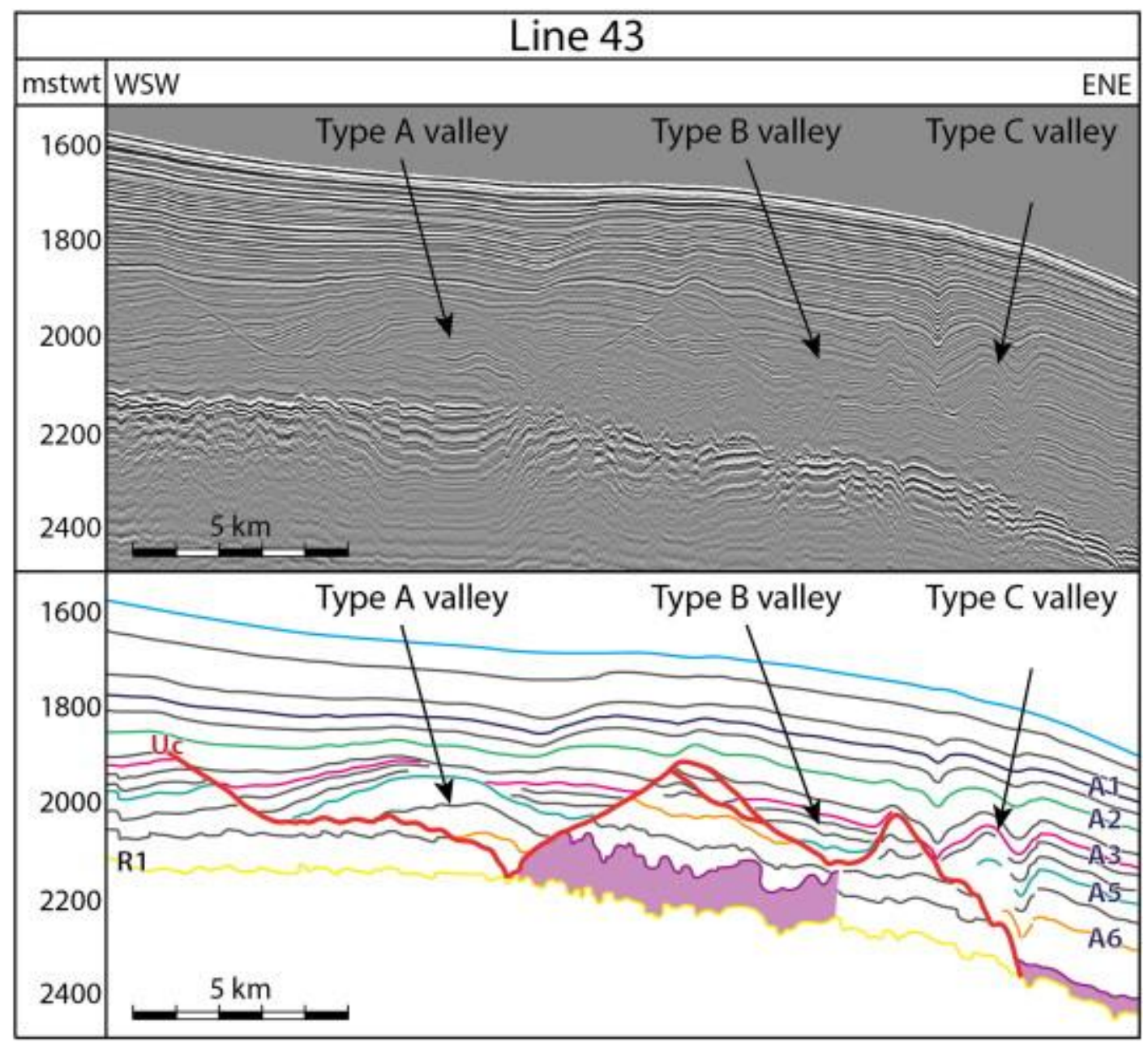


Figure 7: Location map of the valleys and cross cutting direction. On this figure, a different color has been attributed to each single valley (Color lines correspond to picking of valleys on seismic lines).

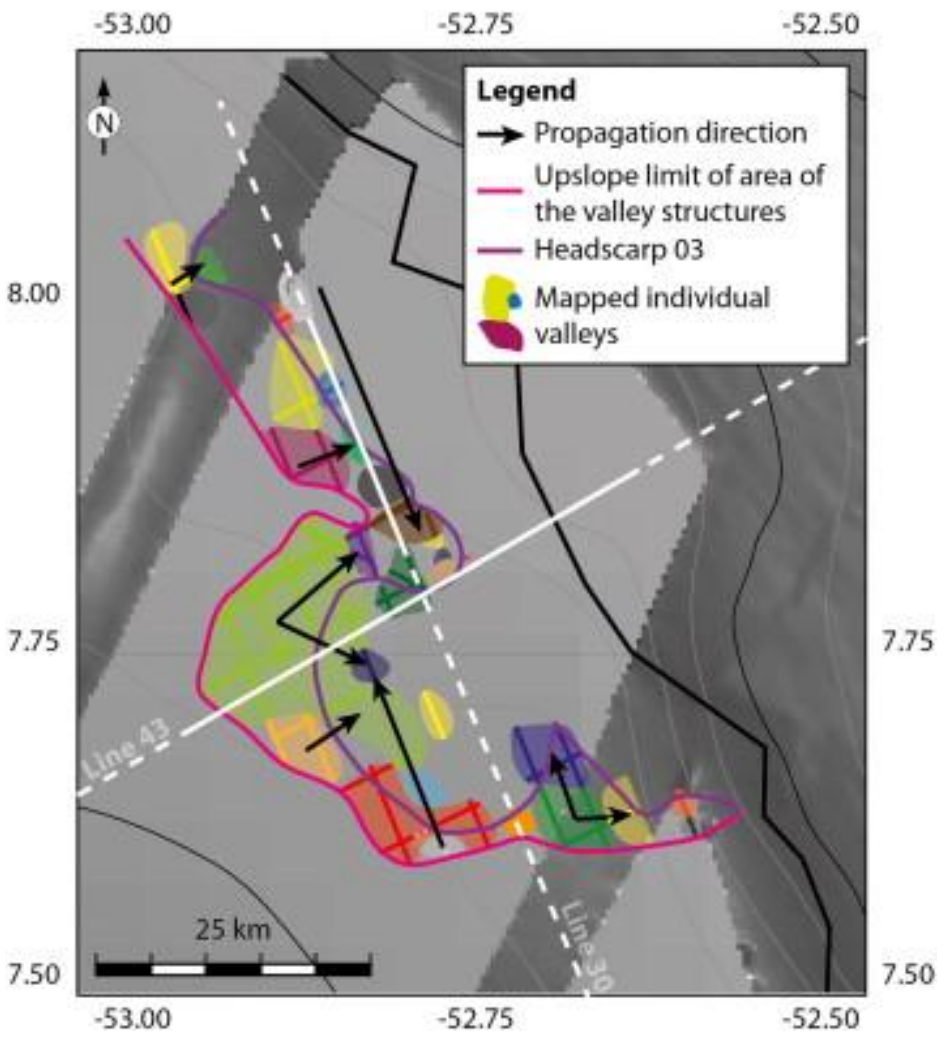


Figure 8: A to C Valley on FG02 seismic lines 09 (A), 10 (B) and 33 (C) (Vertical Exaggeration 15; See location Figure 8D); D. Two-way travel time map of base of this depressional valley.
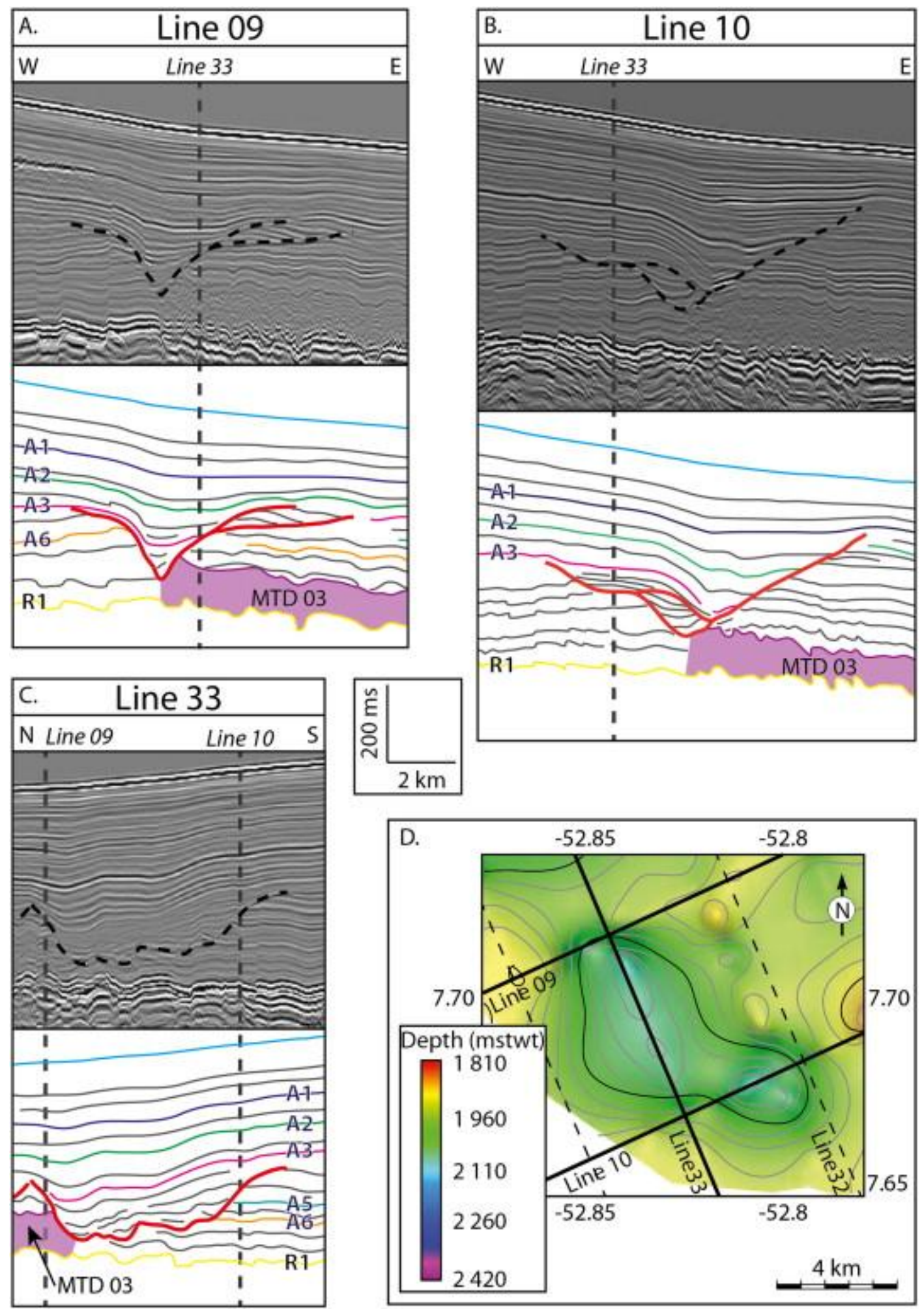
Figure 9: Cross cutting relationships between the valleys on FG02 seismic line 30 (Vertical Exaggeration 15; See location Figure 7).

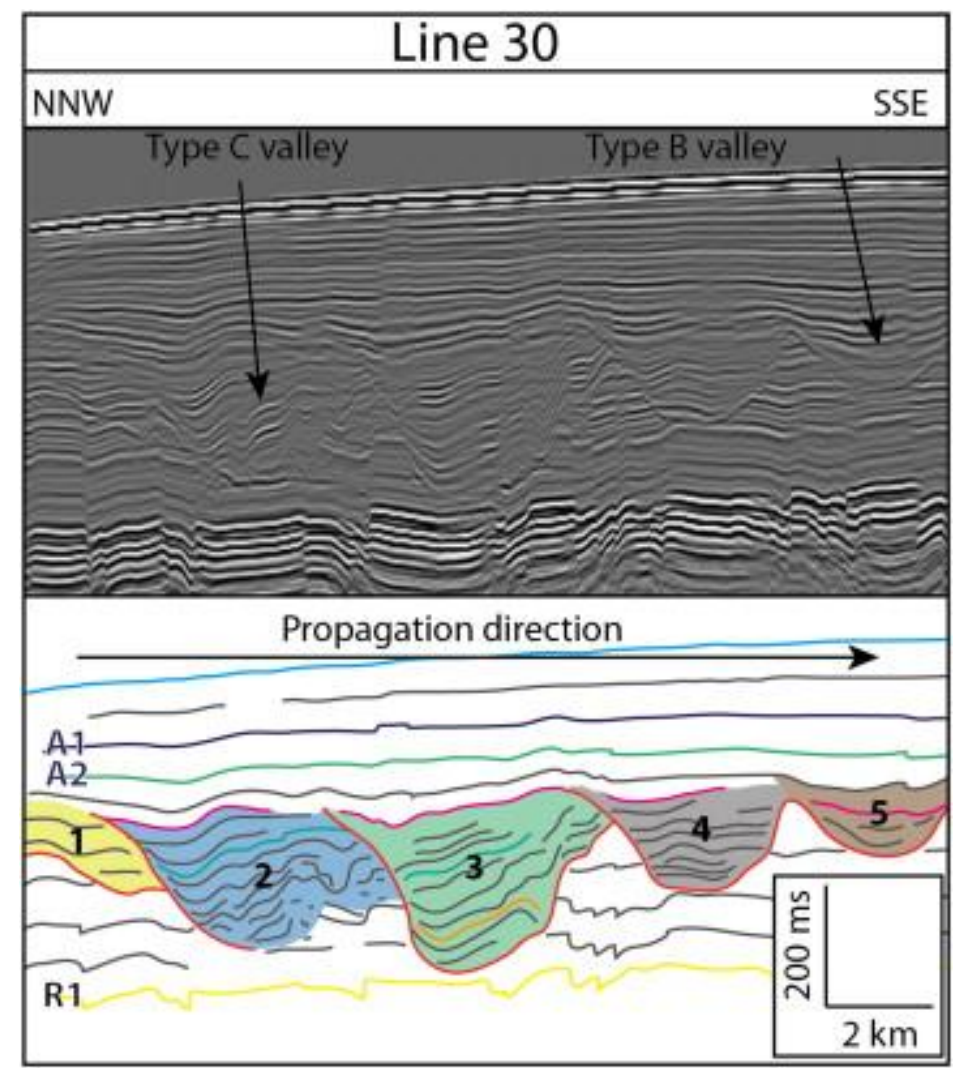


Figure 10: Relationship of Uc unconformity with deeper structures. A. Two-way travel time map of the late Albian unconformity; B. Relationship between the Uc unconformity and a deep fault (FG02 line 02 localized on Figure 10A).

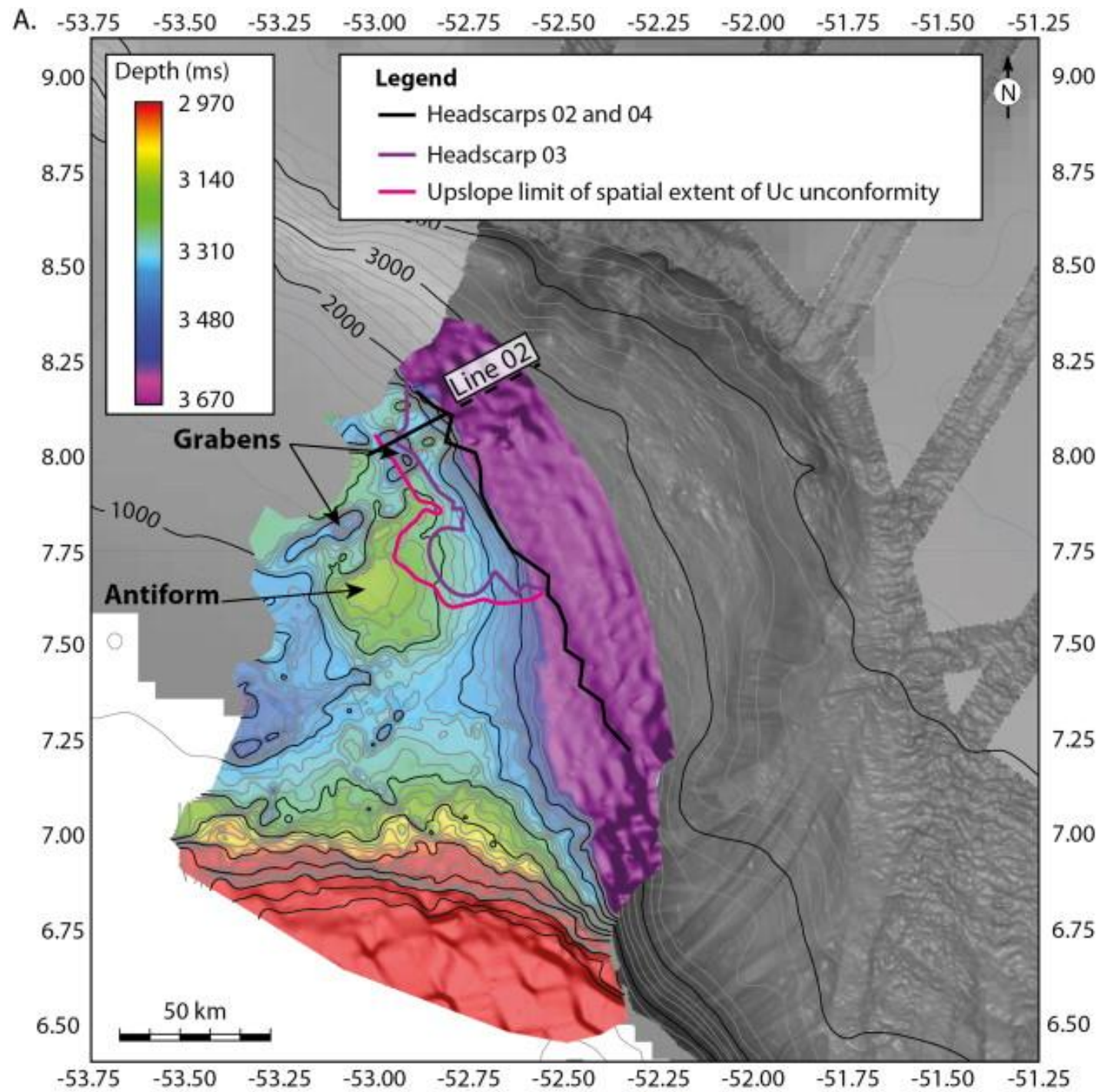

B.

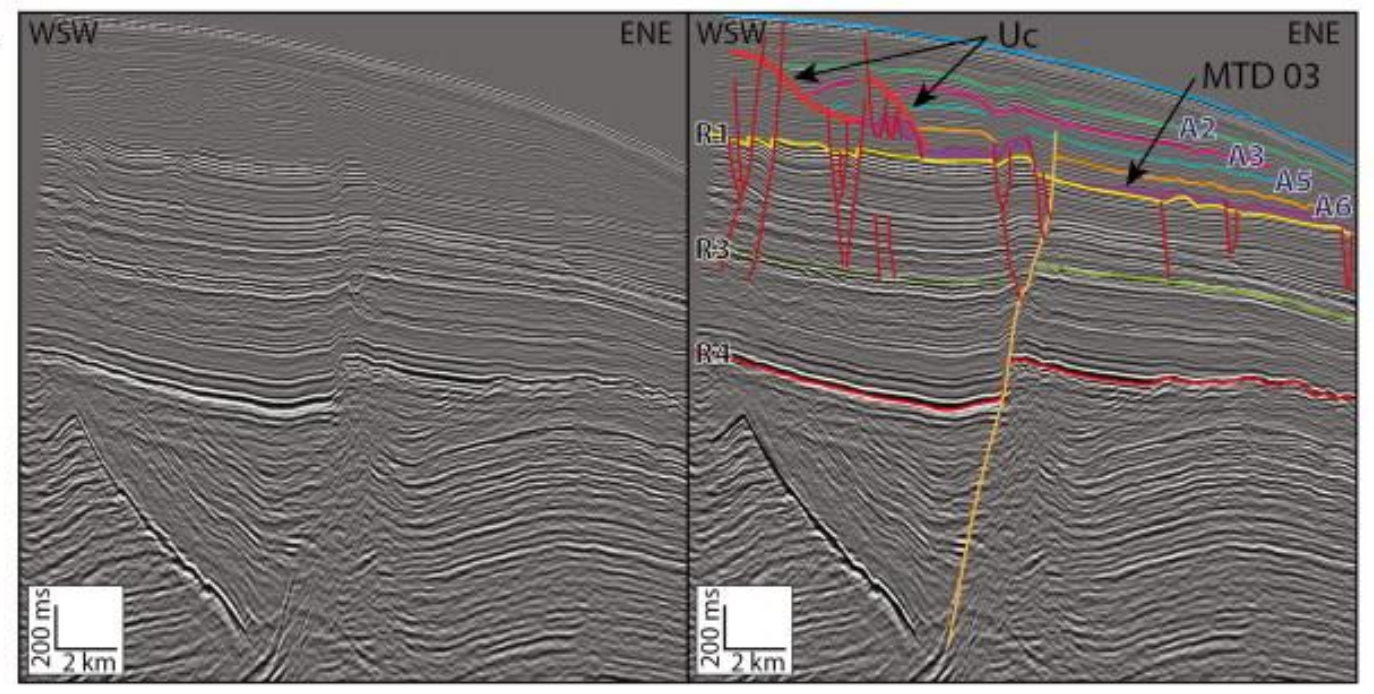


Figure 11: Slope failure hypothesis. A. Headscarp 03; B. Synchronous formation of the first sub-circular depressions; C. Retrogressive propagation of these depressions as inferred in the slope failure hypothesis; $\mathrm{D}$. Centripetal propagation corresponding to the observations.

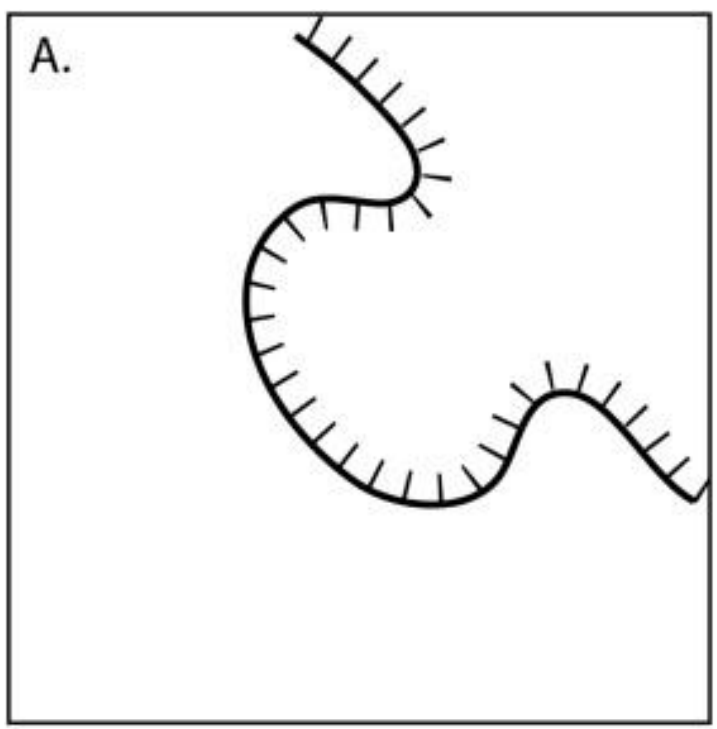

Headscarp 03

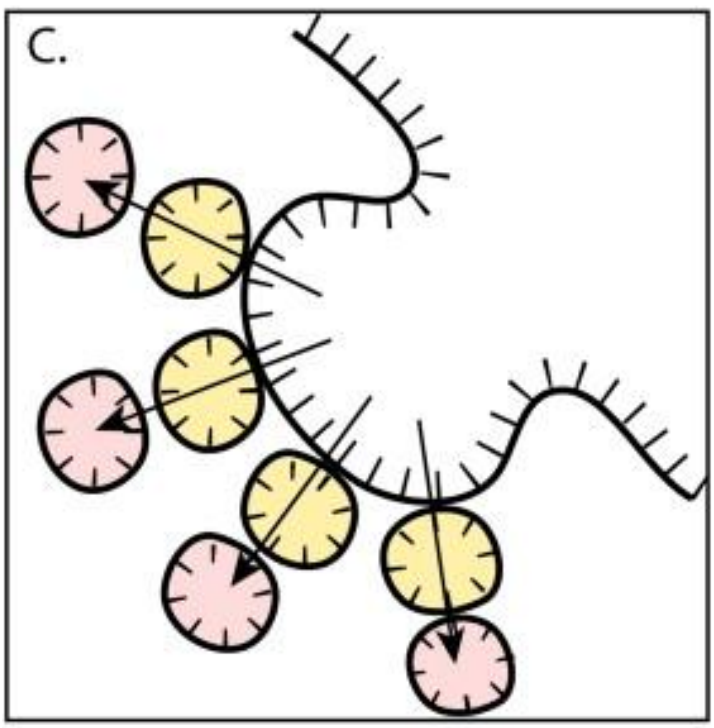

Centrifugal retrogressive propagation

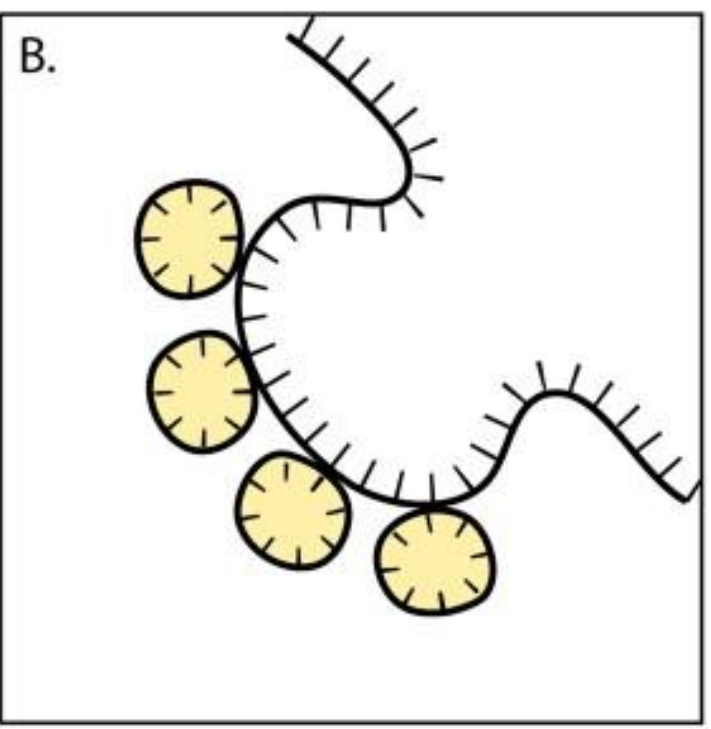

Development of first depressions

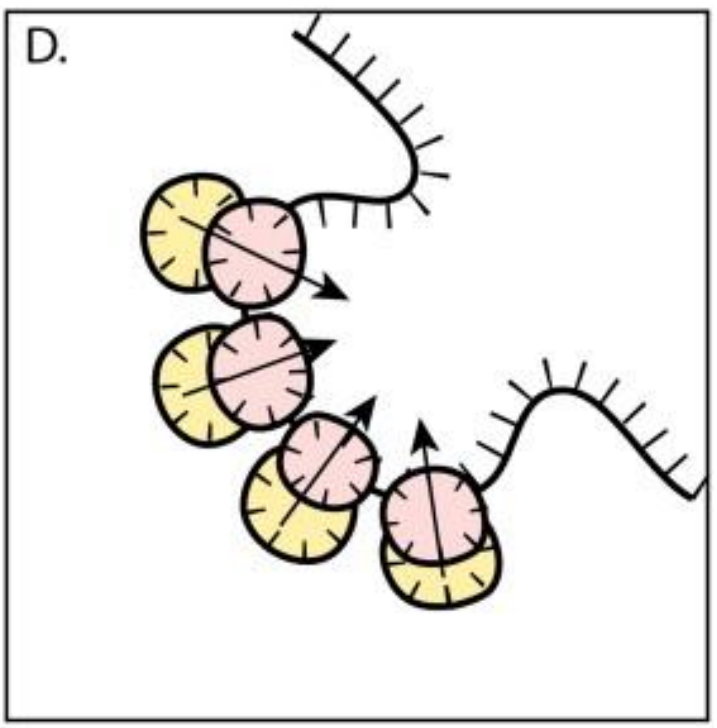

Centripetal propagation 
Figure 12: Schematic reconstitution of events according to the contourite hypothesis. Steps 2 to 3 are easily conceivable. On the contrary, Step 4 (downslope centripetal propagation of depressions) seems much less plausible.

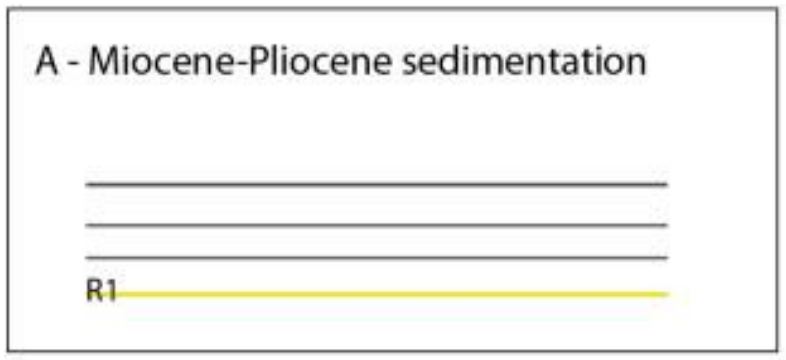

\section{B - Mass destabilization} irregular bathymetry: positive reliefs

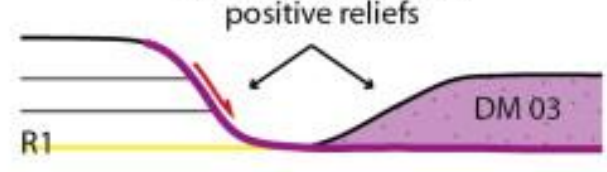

C - Establishment of contouritic system

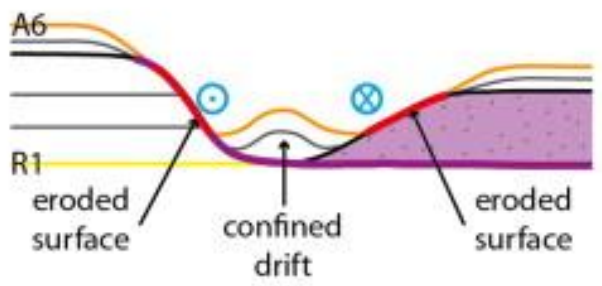

\section{D - Establishment of new depression}

\section{Predicted}

Downslope propagation direction?

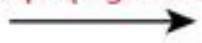

new irregular

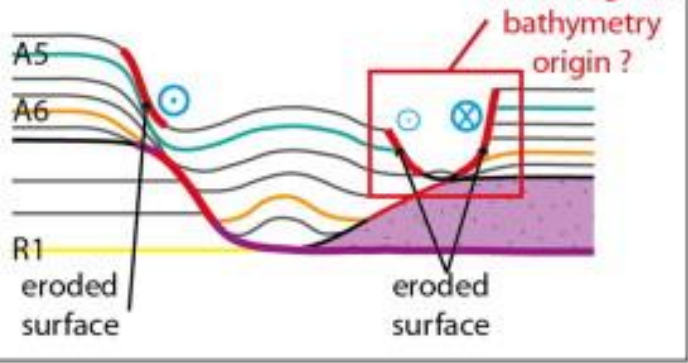

\section{Observed}

Downslope propagation direction

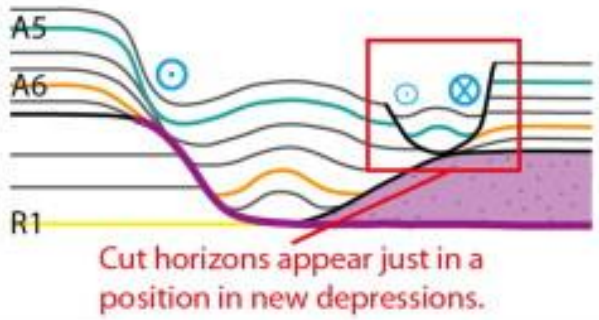


Figure 13: Evolutionary scenario of Demerara hydrate pockmarks.
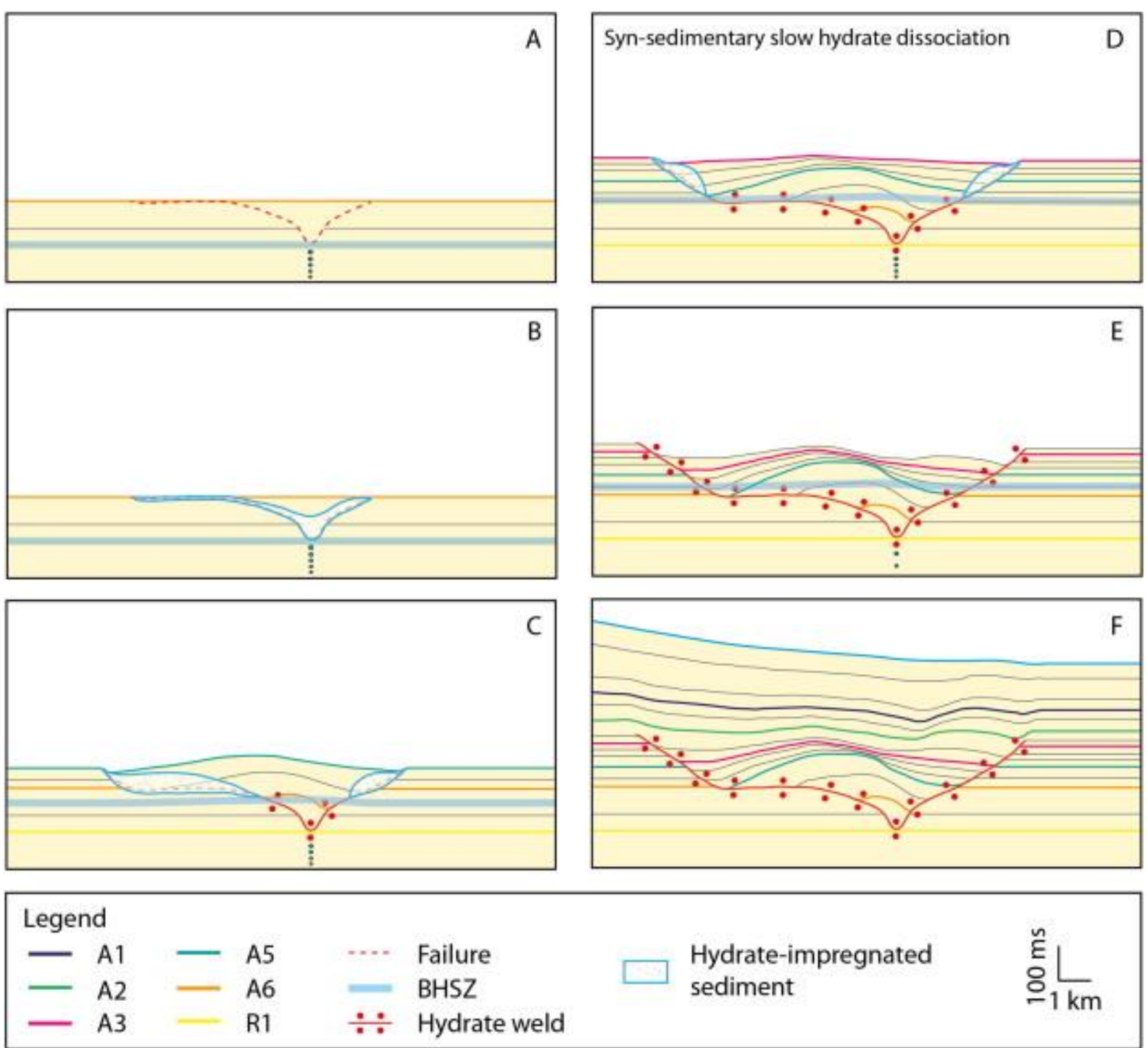

Hydrate-impregnated sediment

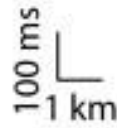

